Historic, Archive Document

Do not assume content reflects current scientific knowledge, policies, or practices. 



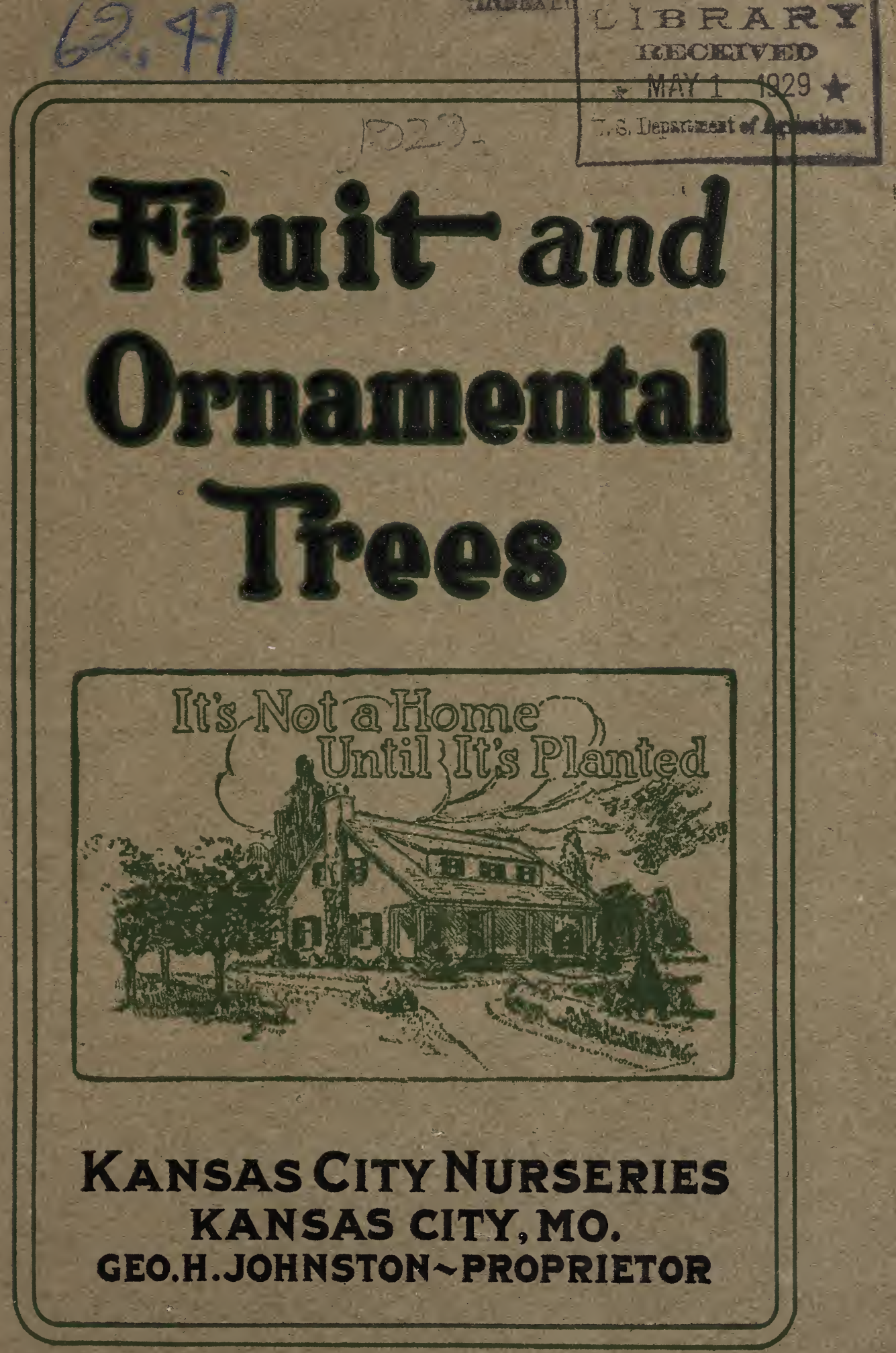




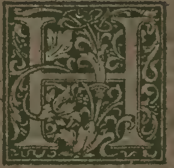

ONEST and liberal transactions with our customers, knowing our stock and meeting the demands of our customers are facts upon which the success of the Kansas City Nurseries is based. These in a wellmanaged and well regulated institution always bring success. In presenting you this, our latest descriptive catalog, we therefore solicit your continued patronage believing it will be to your interest as well as ours for the following reasons:

First. We have been in the nursery business for many years, thereby attaining a full and complete knowledge of what varieties are giving the best satisfaction in this locality; also of the best mode of propagating and growing stock, and of handling and caring for it when transplanting.

Second. It has been acknowledged by all who have visited our nurseries that we have the best assortment of beautiful and well-developed Evergreens, Flowering Shrubs, etc., that can be found in any nursery in the West. In this we have accomplished our desire to be able to supply the Western trade with Western-grown stock.

Third. We are not making a specialty of growing a few sorts, such as apples, peaches and cherries, but have a general nursery, thereby enabling the purchaser to select from a complete assortment of fruit, deciduous and evergreen trees, flowering shrubs, vines, roses, bulbs, etc., that are of superior quality and at less cost than the same stock can be secured from Eastern nurseries.
Fourth. Our location is in the center of a great fruit-producing country. New sorts are continually being tested, and either placed on the list as being worthy or discarded, thus enabling us to obtain the very best approved varieties.

Fifth. Kansas City is the acknowledged great railroad center of the West, making our railroad facllties for quick transportation for per ishable goods one of the best. We are enabled to ship direct to all points without the risis of delay in transferring stock from one railroad to another.

Sixth. The advantages of our nursery-grown shade or street trees over those obtained from the forest. The transplanting of trees into nursery rows, together with the thorough cultivation they recelve, causes them to form an abundance of root, making them more vigorous and healthy, and when transplanted by purchaser, they will make a strong growth from the start, thus enabling them to resist the hot rays of the summer sun.

\section{The KanSAS GITY NURSERIES}

GEO. H. JOHNSTON, Prop.

\section{KANSAS GITY, MISSOURI}

518 Reliance Bldg., N. W. Cor, 10th and McGee. Phone 0370 Harrison

Nurseries located at Wilder and Kansas Avenue and Carlisle Road, K. C.. Kas. Nursery Phone, Argentine 0967 


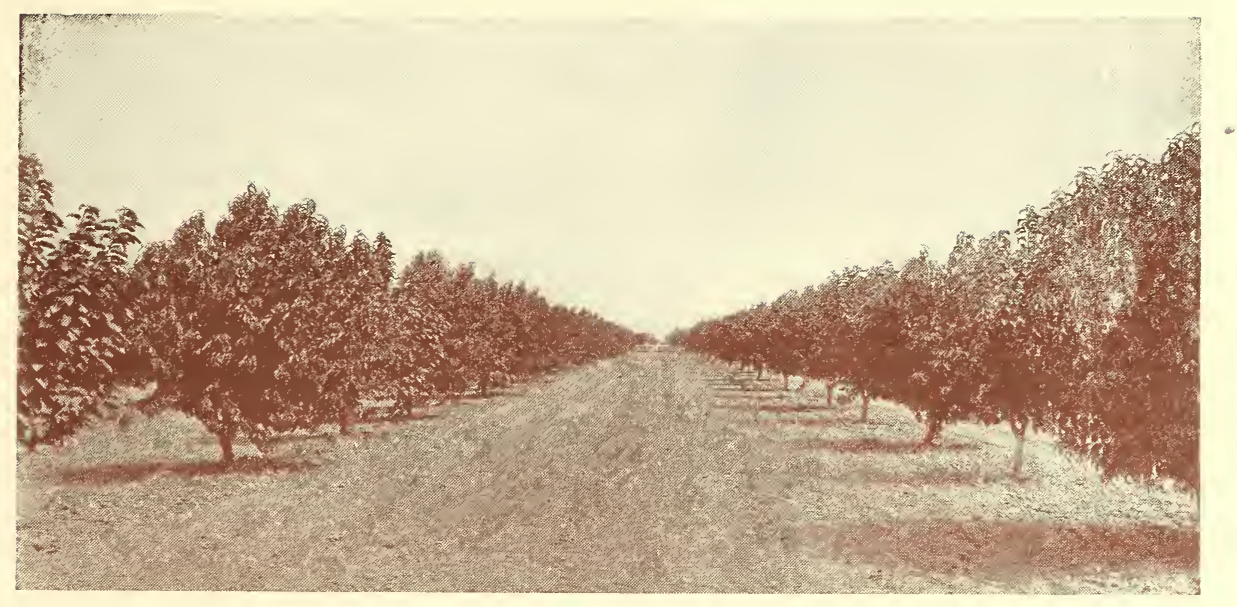

\section{Please Read Before You Order}

In preparing this catalog it is our desire and aim to make the descriptions and time of ripening, etc., as accurate and intelligent as possible, and, in so doing, lend assistance to those desiring to make a selection, so as to obtain varieties suited to their locality, and also that a succession of ripening from the earliest to the latest may be obtained.

\section{Advice to Correspondents}

Send in Your Orders as early as possible, so that there may be no delay at the time of shipment. All orders will receive prompt attention.

Use the Order Sheet. All orders should be written out on the order sheet and not mixed up in the body of the letter. This will save much trouble, and, at the same time, prevent mistakes.

In Ordering Fruit Trees, state whether standards or dwarfs are wanted; also the age, size and number desired.

Substitution. When particular varieties are ordered, state if substitution is allowed and to what extent, in case the order cannot be filled as ordered, as sometimes is the case in all nurseries. When no instructions are given, we will use our best judgment so as to render the best satisfaction to the customer.

Shipping Directions. Give explicit directions for marking and shipping stock. In case no directions are given, we will ship the cheapest and most direct route by freight, unless it is deemed safest and best to ship by express. In all cases, the shipment will be at the risk of the purchaser, and if delay or loss occurs in transit, the forwarders alone must be held responsible.

Orders from Unknown Correspondents must be accompanied with a draft, postoffice or express money order for the amount. If neither can be obtained, enclose currency in registered letter.

Errors. Customers are requested to send notice at once of any error that may be made in filling their order, so that it may be rectified and explained.

Articles by Mail. Packages of small articles will be sent by mail, postpaid, for the convenience of those who can not be reached by railroad or express.

The Shipping Season. There can be no definite time specified for beginning to ship, either in the spring or fall. That is regulated by the opening of the spring-early or late-and by the ripening of the stock in the fall; as the season for planting is not regulated so much by any particular month or day, nor by the state of vegetation, but more particularly by the condition of the trees to be planted. It is therefore better that orders be sent in early so the stock can be shipped or delivered at the proper season in good condition. 


\section{Guarantee of Genuineness}

While the greatest diligence and care to have all trees, etc., true to label, will be exercised, mistakes may occur, and, in such cases, upon proper proof, the trees, etc., will be replaced free of charge, or the amount refunded; but it is mutually understood and agreed to between the purchaser and ourselves that the guarantee of genuineness shall in no case make us liable for any sum greater than that originally paid for the trees, etc., that proved untrue, nor for damage.

\section{Remarks}

Great developments have been and are still being made in the creation of new fruits; and, while many of the new varieties have not maintained their first representations, some have proved even more valuable than was at first anticipated and must be considered as very valuable acquisitions. This is more especially so among the plums and small fruits. But, in examining a catalog, one thing cannot help but be observed; that the old leading sorts still maintain their place at the very head of the list and, therefore, in the revision of this catalog, care has been taken to leave out such varieties as are not considered valuable, and only such varieties are given place as are now in general cultivation (some of which will succeed well only in certain locations), so that by a judicious selection from the list, a model orchard may be obtained.

\section{Hints on Transplanting}

The natural place for the roots of trees and plants is in the ground, and as soon as they are exposed to the atmosphere and become too dry, they begin to lose their vitality; there. fore, let it be kept in mind that too much care cannot be taken to protect their life and vitality while out of the ground, as a failure in this is often the cause of a feeble growth when transplanted. Poor growth is also caused by not having the ground in proper condition at time of transplanting and a lack of after-cultivation.

Soil, Its Preparation, Exposure, etc. Any soil that will grow good crops of corn and small grain will answer for fruit trees, etc. Eastern and northern exposures are usually considered best, but perhaps more depends on the quality of the soil and its preparation and after-cultivation than on the exposure. If the ground is naturally wet, spouty and cold, artificial draining is necessary before planting. Any ground should be well prepared by twice plowing, using the subsoil plow after the common one at the second plowing, and stirring the ground 20 inches or more deep; the deeper the better. This is not only for trees, but small fruits as well. On good, rich soil, manuring will be unnecessary, but on thin or poor soil, fertilizers, such as decomposed manure or compost should be applied freely. Never grow small grain in the orchard, but always some crop that will require thorough cultivation, and the rows of trees should be kept cultivated at least until the latter part of August.

Transplanting. When the trees are received, open the bundles and heel in, so that mellow earth will come in contact with all the roots. It may be necessary to apply water to moisten the soil. Before planting, the ends of all bruised and broken roots must be cut, sloping from the under side. If the soil is properly prepared, the holes need not be dug much larger than to receive the roots in their original position. In planting in sod, in yard or lawn, the hole should be dug 4 to 6 feet in diameter and a little deeper than is necessary to set the tree, always using good mellow soil in filling in, pressing the ground well about the roots, and in such a manner as to leave them in their natural position as much as possible. Water freely used in planting helps to settle the earth about the roots. Mulching, as soon as the tree is planted 3 or 4 inches thick, and 4 to 6 feet in diameter, should be applied, but the earth should be well pressed about the tree before applying the mulching.

Depth to Plant. About the only correct guide that can be given in regard to the depth to be planted is that when the ground is well pressed about the tree or plant it will be as deep or a little deeper than it stood in the nursery; and in this it is well to bear in mind that the roots of some trees, such as the standard pear, strike their roots deep, and require a deep hole, even to plant them as deep as they were in the nursery. Dwarf trees should be planted so that all the stock on which they are worked will be well wnder ground.

Pruning. Cut back one-third to one-half of last season's growth, and one-year-old peach to almost a bare stock, and headed back to the desired height, for forming the top; the buds on the body of the peach tree will make a better growth and form a better top than if the side branches are left on. It is not advisable to do this close pruning until just before the buds start in the spring. Remove the labels before the trees begin to grow. 


\section{Wintering Trees When Procured in the Fall}

Procuring trees in the autumn for early spring planting is recommended when the purchaser is not prepared to plant in the fall or prefers spring setting, or where the winters are too severe to set out young trees or plants in the fall; the greatest advantages derived in doing so are that when the roots have been cut or pruned, it will be found upon taking them up in the spring, that a callous has been formed ready for the producing of new rootlets and the trees being planted without much exposure, as soon as the frost is out of the ground, will become thoroughly established the first season, and should make twice the growth of late-planted trees; and the labor or planting is then done before the rush of the spring work sets in. To insure success, select a dry spot of ground where water will not stand during winter, and no grass or litter that will invite mice.

Dig a trench from 3 to 4 feet wide, according to the amount of trees to be heeled in, and deep enough to admit one layer of roots and sloping enough to let the trees lie at an angle of about 30 degrees, throwing the earth on the back part of the trenches so as to make a more perfect slope on which to lay down the trees. Put in one layer of trees, placing the roots as close together as can conveniently be done, cover with well-pulverized soil, well up on the bodies and as carefully worked in about the roots as if they were being planted; then add another layer of trees, overlapping the first, and continue as at first until all are heeled in, throwing the ground well up around the trench, and when the winters are very severe it is advisable to cover the trees entirely up with earth. Evergreen boughs, coarse straw, or corn fodder can be placed over the tops, but not thick enough to admit a harbor for mice. The roots should be pruned before laying them down in the fall.

\section{Treatment of Trees, Etc., That Have Been Frozen in the Packages or Received During Frosty Weather}

Put them unopened in a cellar or some other cool, protected place, free from frost, or cover them up heavily or entirely with earth until they are fully thawed out, when they can be unpacked and planted or placed in trenches until convenient to plant. Treated in this way they will not be injured by the freezing.

\section{Suitable Distance for Planting}

\begin{tabular}{|c|c|c|}
\hline & Feet & Feet \\
\hline Apples, Standard & .25 to 40 & Grapes . \\
\hline Apples, Dwarf . & . 6 to 8 & Currants ... \\
\hline Pears, Standard & .18 to 20 & Gooseberries \\
\hline Pears, Dwarf ... & .10 to 12 & Raspberries, Red . \\
\hline Peaches ....... & .16 to 18 & Raspberries, Black \\
\hline Nectarines and & .16 to 18 & Blackberries ............ \\
\hline Cherries, Sweet & .18 to 20 & Strawberries, in rows..... \\
\hline Cherries, Sour. & .16 to 18 & Strawberries, in beds..........11/2 by $11 / 2$ \\
\hline Plums $\ldots \ldots \ldots$ & .18 to 20 & Asparagus, in beds ............. \\
\hline aces & . 8 to 10 & Asparagus, in field...... \\
\hline
\end{tabular}

\section{Number of Trees and Plants on an Acre at Various Distances}

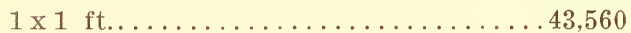

$2 \times 1$ ft..............................

$2 \times 2$ ft...................... 10,890

$3 \times 1$ ft....................... 14,520

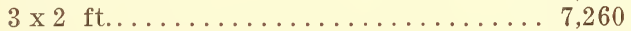

$3 \times 3$ ft......................, 4,840

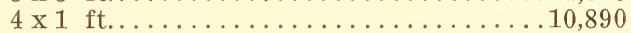

$4 \times 2 \mathrm{ft} . \ldots \ldots \ldots \ldots \ldots \ldots \ldots \ldots, \ldots \ldots \ldots, \ldots \ldots$

$4 \times 3 \mathrm{ft} . \ldots \ldots \ldots \ldots \ldots \ldots \ldots \ldots \ldots \ldots \ldots, 630$

$4 \times 4 \mathrm{ft} . \ldots \ldots \ldots \ldots \ldots \ldots \ldots \ldots \ldots \ldots \ldots \ldots, 2,722$

$5 \times 2 \mathrm{ft} . \ldots \ldots \ldots \ldots \ldots \ldots \ldots \ldots \ldots, 4,356$

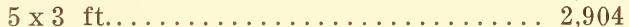

$5 \times 4 \mathrm{ft} . \ldots \ldots \ldots \ldots \ldots \ldots \ldots \ldots \ldots \ldots \ldots \ldots \ldots, 178$
$5 \times 5 \mathrm{ft} . \ldots \ldots \ldots \ldots \ldots \ldots \ldots \ldots \ldots \ldots \ldots \ldots, 742$

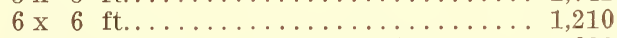

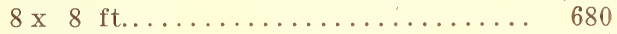

$10 \times 10 \mathrm{ft} . \ldots \ldots \ldots \ldots \ldots \ldots \ldots \ldots . \ldots . \ldots . \ldots . \ldots 45$

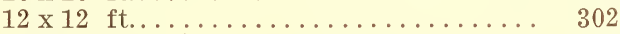

$15 \times 15$ ft.................... 193

$16 \times 16 \mathrm{ft} \ldots \ldots \ldots \ldots \ldots \ldots \ldots \ldots \ldots \ldots$

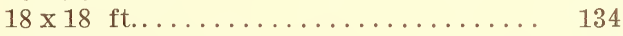

$20 \times 20 \mathrm{ft} \ldots \ldots \ldots \ldots \ldots \ldots \ldots \ldots \ldots . \ldots \ldots$

$25 \times 25$ ft......................... 69

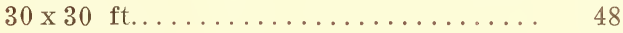

$33 \times 20 \mathrm{ft} \ldots \ldots \ldots \ldots \ldots \ldots \ldots \ldots 6 . \ldots \ldots$

The number of plants required for an acre, at any given distance apart, may be ascertained by dividing the number of square feet in an acre $(43,560)$, by the number of square feet given to each plant, which is obtained by multiplying the distance between the rows by the distance between the plants. Thus, strawberries planted 3 feet by 1 foot gives each plant 3 square feet, or 14,520 plants to the acre. 


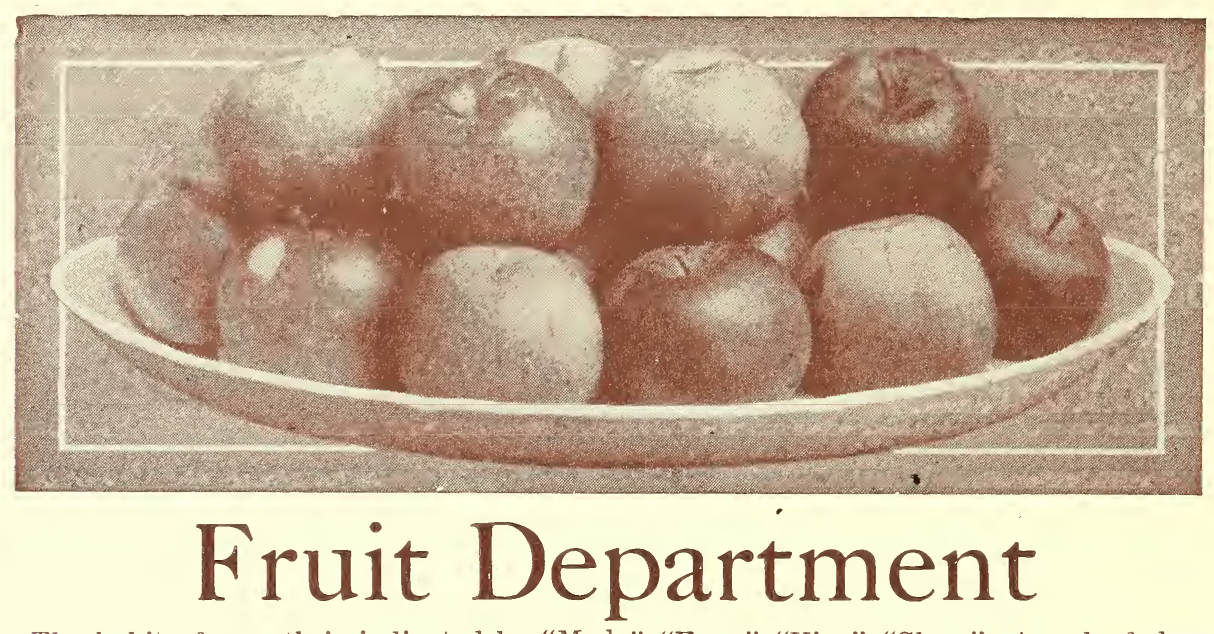

The habit of growth is indicated by "Mod.," "Free," "Vig.," "Slow," at end of description. meaning moderate, free, vigorous or slow growers.

The season of ripening after habit of growth, embraces that portion of country between parallel 39 and 40. This takes in Dayton, O., Indianapolis, Ind., Springfield, Ill., Kansas City, Mo., and Topeka, Kan. The season of ripening will be earlier or later in proceeding south or north.

Directions for spraying will be found in the last pages of this catalog.

\section{Apples}

The past few years have witnessed the shipment abroad of thousands of barrels of

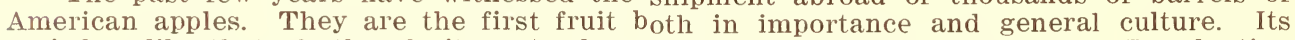
period, unlike that of other fruits, extends nearly or quite through the year. By planting judicious selections of summer, fall and winter sorts, a constant succession can be had of this indispensable fruit.

\section{Summer Apples}

Astrachan Red. Large, roundish, beautifully marbled with crimson, covered with a heavy bloom; a good bearer. Free. July.

Benoni. Medium, roundish; pale yellow, shaded with crimson; juicy, tender and sub-acid. August.

Carolina Red June (Red June). Medium; red; the flesh is white, tender, juicy and sub-acid. The tree is an abundant bearer. Last of June.

Chenango Strawberry. (Sherwood's Favorits). Medium, oblong and indistinctly ribbed; skin whitish, splashed and mottled light and dark crimson; the flesh is white, tender and juicy, with a mild, sub-acid flavor. Valued for the table. Vigorous and a good bearer. Aug. and Sept.

Oldenburg. A Russian variety of medium to large size, of good shape; skin yellow, streaked with red, somewhat blushed, and sometimes with a faint blue bloom; flesh juicy, and good, with a rich sub-acid flavor. Productive. Slow. Aug.

Lowland Raspberry. Fruit good sized, clear, waxen white striped crimson; flesh snow white; blooms late; is blight resistant; bears early.

Early Harvest. Medium to large, roundish; bright straw-color; flesh white, tender, juicy, crisp, with rich sub-acid flavor. First of July.

Yellow Transparent (Russian Transparent), Grand Sultan). Ripens with Early Harvest and the fruit will keep fully ten days after ripening, making it valuable for early shipping. Fruit of medium size and good quality; skin clear white, changing to beautiful yellow when ripe. Slow.

\section{Autumn Apples}

Maiden's Blush. Rather large, oblate, smooth and regular; pale yellow, with beautiful red cheek; flesh white, tender, sprightly, with a pleasant sub-acid flavor. An abundant bearer. Free. Aug. and sept.

Wealthy. A native of Minnesota, and one of their hardy sorts. An apple of fine appearance and good quality; in size it equals the Baldwin, and is better for dessert. One of the most productive varieties, sometimes almost killing itself with its early and excessive bearing. Valuable for market.

\section{Winter Apples}

Ben Davis (New York Pippin). Medium to large, roundish; skin yellowish, splashed and striped and almost covered with red; the flesh is white, tender, moderately juicy, sub-acid. The tree is very hardy, a free grower, and comes into bearing early. 
A valuable feature is its blooming late in the spring, thereby escaping late frosts. Highly esteemed in the West. Dec. to March.

Delicious. Fruit large, nearly covered with brilliant dark red, flesh fine grained, crisp and melting, juicy, with a delightful aroma; of very highest quality. A splendid shipper. Tree one of the hardiest, a vigorous grower, with good foliage. A regular annual bearer.

Grimes' Golden (Grimes' Golden Pippin). Medium to large in size, and of the highest quality. A bright yellow apple, which grows and bears well in every section of the country. Hardy, vigorous and productive. Nov. to Dec.

Gano. Originated in Missouri. Large, oblong, tapering to the eye; the fruit is bright red on yellow ground, with no stripes, flesh pale yellow, fine-grained, tender, pleasant, mild sub-acid. The tree is healthy, vigorous, hardy and an early and annual bearer. Jan. to April.

Ingram. A seedling of Janet. Medium, roundish, inclined to conical, smooth; yellow ground, striped bright red; flesh greenish yellow, delicate, tender, juicy, sub-acid. A late keeper.

Jonathan. Medium, roundish; skin yellowish, nearly covered with dark or lively red; fine-grained, very tender and finely flavored. Mod. Oct. to Dec.

Arkansas (M. B. Twig). Fruit large, often measuring 12 inches in circumference. Excels Winesap in nearly every important point, the color being even a darker red, the flesh firmer, flavor milder, but fully equal. The tree is a fine, upright, spreading grower, and bears large crops and holds fruit well. Vig. Nov. to April.

Minkler. Fruit medium, roundish, oblate, slightly conical; pale greenish yellow, striped and splashed with two shades of red; flesh yellowish, compact, moderately juicy, mild, pleasant, sub-acid. The tree is an irregular grower. Vig. Jan. to April.

Rawle's Janet (Never Fail). Medium, roundish, ovate; greenish yellow, striped with red; crisp, rich and juicy. Mod. Jan. iu May.

Roman Stem. Medium; whitish yellow, splashed with russet; has rich, pleasant, musky flavor; flesh tender, juicy. Fine dessert apple. Mod. Nov. and Dec.

Stayman's Winesap. Medium size, round, approaching conical; skin smooth, greenish yellow, splashed and striped with red and purple; flesh yellow, firm, tender, juicy, rich, mild, sub-acid and aromatic. An early bearer and very productive. Jan. to May.

Winesap. Medium; dark red; sub-acid. Tree an abundant bearer. One of the finest cider apples grown, both on account of its overabundance of juice and its productiveness. Vig. Nov. to April.

York Imperial. Medium, oblate; white, shaded with crimson; flesh firm, crisp, juicy and sub-acid. A splendid bearer and keeper and equally valuable for the table or for cooking. Mod. Nov. to April.

\section{Crab Apples}

General Grant. Fruit large; red to very dark red; flesh white, tender, mild, sub-acid. Fine for dessert. Free. Oct.

Hyslop. Almost as large as Early Strawberry apple; deep crimson; flesh inclined to yellow, sub-acid. Popular on account of its large size, beauty and hardiness. Vig. Sept. and Oct.

Red Siberian. About an inch in diameter and grows in clusters; yellow, lively scarlet cheek. Tree large with coarse foliage; bears young. Vig. Aug. and Sept.

Transcendent. The fruit is from $1 \frac{1}{2}$ to 2 inches in diameter; skin yellow, striped with red; the tree is perfectly hardy and a young and abundant bearer. Vig. Aug. and Sept.

Whitney's No. 20. One of the largest; skin smooth, glossy, green, striped and splashed with carmine; flesh firm, juicy and rich. Tree a vigorous handsome grower, with dark green glossy foliage. Aug. and Sept.

\section{Pears}

The growing of this noble fruit is rapidly extending as its value is appreciated, and the demand for it, both green and dried, is increasing every year. It is a mistaken idea that standard pears are a long time coming into bearing; many varieties begin to bear in from four to six years after transplanting, and some of the varieties, such as Kieffer, will produce fruit as soon as the dwarf pears, which is usually two to three years after transplanting. The pear when once in bearing seldom fails to produce a crop of fruit annually.

Gathering Pears. In order to retain the juice and best flavor, summer pears should be gathered at least ten days before they are ripe, and autumn pears at least two weeks; winter varieties, as soon as the leaves begin to drop.

The letters "D" and "S" following the varieties indicate favorable growth either as "Dwarfs" or "Standards" or both. Those designated as moderate growers are usually smaller trees. 


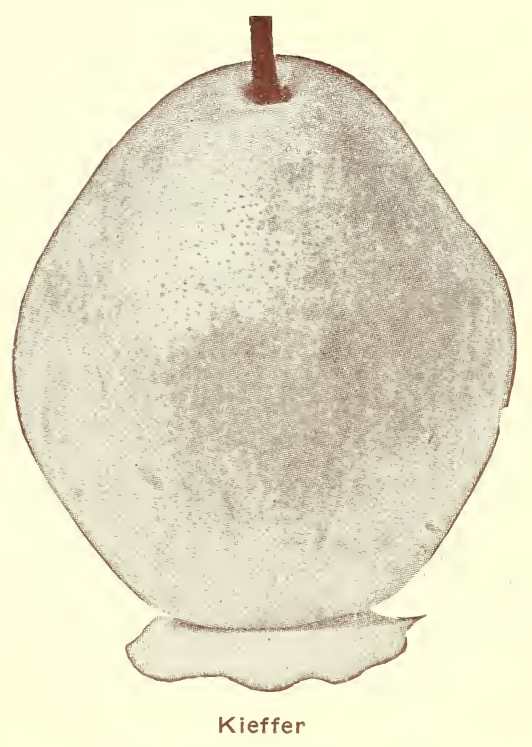

Summer Pears

Bartlett. D. and S. Large, often with a beautiful blush to the sun; buttery, juicy and high-flavored. The beauty, size and excellence of the fruit and productiveness of the tree leave little to be desired and make it very popular. Vig. Aug.

Wilder; Early. D. and S. Medium; greenish yellow, with a brownish red cheek and numerous dots; flesh white, fine grained, melting, excellent. One of the best keeping early pears. Ripens about three weeks earlier than Bartlett.

\section{Autumn Pears}

Beurre d'Anjou. D. and S. A large, fine pear. Greenish, sprinkled with russet, sometimes shaded with dull crimson; flesh white, buttery, melting, with a high, rich, vinous flavor. The tree is very productive and succeeds well on quince. One of the very best autumn pears. Vig. Sept. to Dec.

Duchesse d'Angouleme. D. Very large; dull greenish yellow, streaked and spotted with russet; flesh white, buttery and very juicy, with a rich and excellent flavor. Always fine on the quince, to which it seems well adapted. A general favorite on account of its large fruit and fine appearance. Vig. Sept. and Oct.

Flemish Beauty. D. and S. Large; redcheeked; juicy, melting, rich and fine. A beautiful variety. A good bearer and hardy everywhere. Vig. Aug. and Sept.

Garber's Hybrid. S. A kin to and very much resembles the Kieffer, but is larger, of better quality, and ripens two to three weeks earlier. Yellow as an orange; juicy and rich. The tree is very productive and bears three years after transplanting. Esteemed for market. Sept.

Kieffer's Hybrid. S. Raised from the seed of the Chinese Sand Pear, accidentally crossed with Bartlett, or near it. Of all pears grown for commercial purposes it is the leader. The fruit is of good quality, wonderfully showy, never rots at the core, and is valuable for the table or market. The tree has large, dark green glossy leaves, which make it very ornamental, is an early and prolific bearer, and is as nearly blight-proof as it is possible for any pear to be. Vig. Sept. and Oct.

Seckel. D. and S. Small, but of the highest flavor. Skin rich yellowish brown when ripe, with a dull brownish red cheek; flesh very fine-grained, sweet, very juicy, melting and buttery. Vig. Aug. and Sept.

\section{Peaches}

To secure healthy, vigorous and fruitful peach trees, it requires a well-drained, moderately rich soil, which must be kept clean and mellow-warm, sandy loam is probably the best. Peaches are all borne on wood of the previous season's growth, and this makes it absolutely necessary to prune the trees every year or two, so as to preserve a round, vigorous head. Remove all dead branches. The land should not be seeded to grass, but kept in constant cultivation.

The following have been selected as the best varieties. They furnish a succession for over three months, commencing about July 1st.

Belle. Fruit very large and most attractive in color and shape, with a light red cheek; flesh white, firm and delicious; in all ways the quality is fine. Trees grow quickly and shapely. Hardy; prolific. Free. First half of August.

Champion. A western peach, very large and of good quality. Skin creamy white, with red cheek; delicious, sweet, rich and juicy. Extremely hardy, having stood a temperature of 18 degrees below zero and produced an abundant crop the following season. Freestone.

Chinese Cling. A favorite peach in the South. Large size, oblong; the skin is creamy white, with faint flashes of red. August. 
Crawford's Early. A magnificent, large, yellow peach that is considered very valuable for market purposes. The skin is yellow, with fine red cheeks; flesh yellow, juicy, sweet and excellent. Tree very produc. tive. Free. Last of July.

Crawford's Late. Fruit of the largest size; skin yellow, or greenish yellow, with dull red cheek; flesh yellow. Tree vigorous and productive. One of the finest late sorts. Free. Last of Aug. and Sept.

Crosby. Fruit medium size; bright orange yellow, streaked with carmine; flesh rich, luscious and sugary. An excellent market sort on account of its handsome appearance. Claimed to be the hardiest of all peaches. Freestone with an exceedingly small pit. Sept. 10.

Carman. Large, resembling the Elberta in shape. Creamy white or pale yellow, with deep blush; skin tough; its flesh is white, rich, tender and melting. One of the hardiest in bud. Fine for shipping and is considered one of the best for market. July 15.

Early Elberta. Ripens about a week earlier than Elberta; otherwise the same, or a trifle better quality.

Elberta. Introduced from Georgia. A cross between Crawford and Chinese Cling. Very large. It is the ideal market peach, and a royal fruit from its yellow and red skin to its red stone. Freestone. Aug. 20.

Family Favorite. A seedling of Chinese Cling. Large; clear waxen complexion, with blush; flesh firm. The tree is very productive. Highly esteemed for shipping, canning or drying. Free. Last of July.

Fitzgerald. Of very large size, magnificent quality and a perfect freestone. Skin bright yellow, suffused with red; flesh deep yellow. Aug. 10.

General Lee. An improved Chinese Cling. A very valuable variety. Aug. 20.

Globe. A Pennsylvania variety of great size and beauty. An improvement on Crawford's Late. Rich golden yellow, with red blush; flesh yellow and juicy. Free. Aug.

Greensboro. The largest and most beautiful of all early peaches. It is covered with light and dark crimson, shaded with yellow; flesh is white, juicy and good, and parts clean from the seed when fully ripe. First of July.

Hale. Averages one-third to one-half larger than Elberta, ripens about five days earlier and is much superior in flavor; beautiful golden yellow, with deep carmine blush.

Heath Cling. Large, oblong; creamy white, slightly tinged with red in the sun; tender, juicy, melting, rich and luscious. A popular sort. Sept. 15.

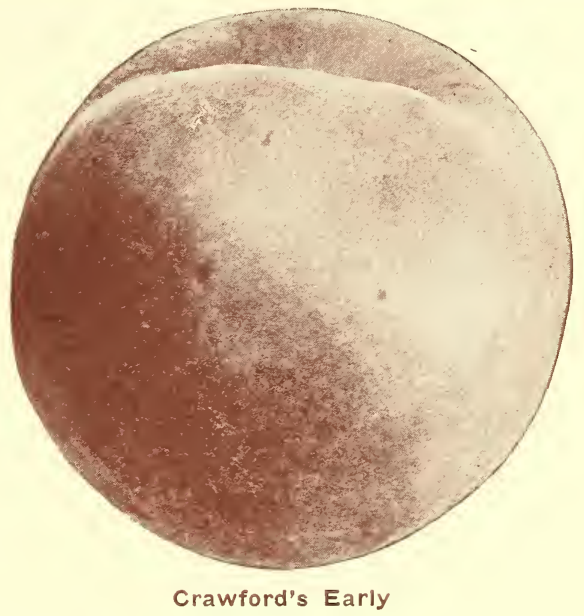

Mammoth Cling. Resembles the above, but double the size. Valuable for preserves. Is superior in every way to Heath Cling. Sept. 20.

Mayflower. Earliest peach known; color red all over, beautiful appearance. Carries well to market. Blooms very late, crop never entirely cut off by late frosts; size medium, quality good. A very prolific bearer.

Mountain Rose. A superb early, white fleshed peach, which yearly adds to its reputation as the best of its season for home or market. Red; rich, juicy, excellent. Free. July.

Oldmixon cling. Large, pale yellow, with deep red cheek; juicy, rich and high-flavored. A favorite clingstone. Aug. 20.

Oldmixon Free. Similar to the above, with the exception that it is a freestone. Aug.

Salway. A rather large, roundish yellow freestone, with a deep marbled brownish cheek; the flesh is yellow, firm, juicy, rich and sugary. A late showy market variety of English origin. Last of Sept.

\section{Apricots}

The apricot is one of the most beautiful and delicious of fruits of the plum species. It ripens very early, which makes it of great value. It is liable to the attacks of the curculio and requires the same treatment as plums.

Early Golden. (Dubois). Small; pale orange; juicy and sweet. Hardy as the Russian and productive. Vig. First of July.

Moorpark. One of the largest. Orange, with a red cheek; firm, juicy, with a rich flavor. Very productive. Vig. July. Russian. Its extreme hardiness and fine quality of fruit make it very valuable. 


\section{Plums}

Diseases and Enemies of the Plum. The great enemy of the plum is the insect known as the curculio, a small, dark brown beetle which punctures the fruit in depositing its eggs from which is hatched the destructive grub, and causing the fruit to drop prematurely and rot. Two ways of destroying this curculio and saving the crop of fruit are recommended, viz:

First. Spread a large sheet, prepared for the purpose under the tree and then jar the tree so as to shake down all fruits that have been stung, as well as all curculios; both insect and stung fruit are destroyed. Begin to do this as soon as the blossoms fall, and keep it up daily, or at least tri-weekly, until the fruit is half grown. The morning is the best time to do this, when the insect is chilled and stupid.

Second. The best remedy and the one generally adopted now doubtless is the spraying of the trees, directions for which are given in the last pages of this catalog. If those who really desire to grow fine crops of this most delicious fruit will try either of these systems and follow it up rigidly, they will be successful.

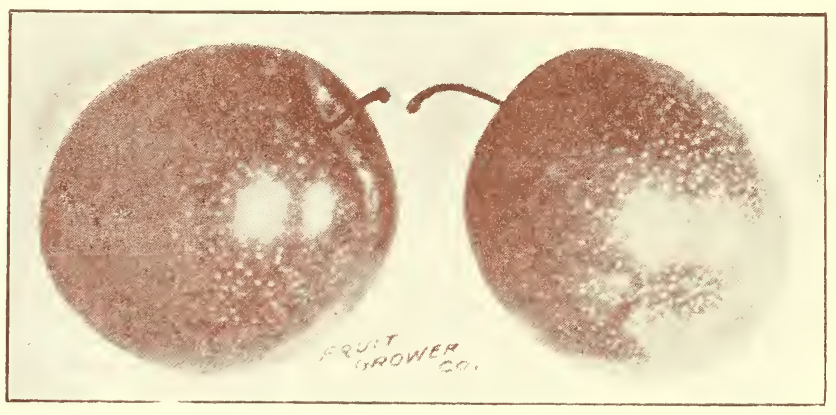

\section{European Plums}

Bradshaw. Very large; dark violet-red; flesh yellowish green, juicy and pleasant. Productive. Vig. Middle of Aug.

Damson. Small, oval; skin purple, covered with blue bloom; flesh melting and juicy, rather tart; separates partly from the stone. Mod. Sept.

German Prune. A large, long, oval variety much valued for drying; the color is dark purple; agreeable flavor. Vig. Sept.

Lombard (Bleeker's Scarlet). One of the most widely cultivated plums in America. Of medium size, round, oval, violet-red, juicy, pleasant and good; adheres to the stone. Vigorous and quite hardy. Valuable for market. Vig. Last of Aug.

Shipper. Originated in northwestern New York, and has never been known to freeze back a particle in the coldest winters. The fruit is large, dark purple; flesh firm and of excellent quality. Splendid for shipping or market. Vig. First of Sept.

Shropshire. As free from the attacks of the curculio as the common Damson of the same color, and commands nearly double the price. Flesh amber, juicy and sprightly. Productive. Free. Last of Sept.

\section{Native American Plums}

Wild Goose. Large; rich crimson; flesh soft, rich, melting, delicious, with a full fruity flavor. The tree is a strong grower and very prolific. July.

\section{Japanese Plums}

America. Is as beautiful as a plum can be, and one of the most dependable; l a r g e, glossy, coral red, almost proof against rot and insect attack.

Abundance (Botan). One of the best Japanese plums. It is one of the imported varieties, being catalogued under the name of Abundance on account of its wonderful bearing qualities. The fruit is large; handsome, and practically curculio-proof; lemon-yellow ground, nearly overspread with bright cherry, and with a heavy bloom; flesh orange-yellow, melting, rich and highly perfumed. The tree is an early and profuse bearer. July.

Burbank. A beautiful, large plum, of nearly globular form. The color is clear cherryred, with a thin lilac bloom; flesh deep yellow, very sweet, with a peculiar and very agreeable flavor. The tree is vigorous, with strong, upright shoots, and commences to bear annually two years from planting. It blooms late and escapes the late spring frosts. Middle of Aug.

\section{Quinces}

Apple or Orange. Large, roundish; bright golden yellow; cooks tender and is of excellent flavor. The tree is very productive. Valuable for preserves or flavoring. Sept.

Champion. Originated in Connecticut. The fruit averages larger than the Orange, more oval in shape, quality equally fine and a longer keeper. The tree is very prolific and a constant bearer. Vig. Oct. and Nov. 


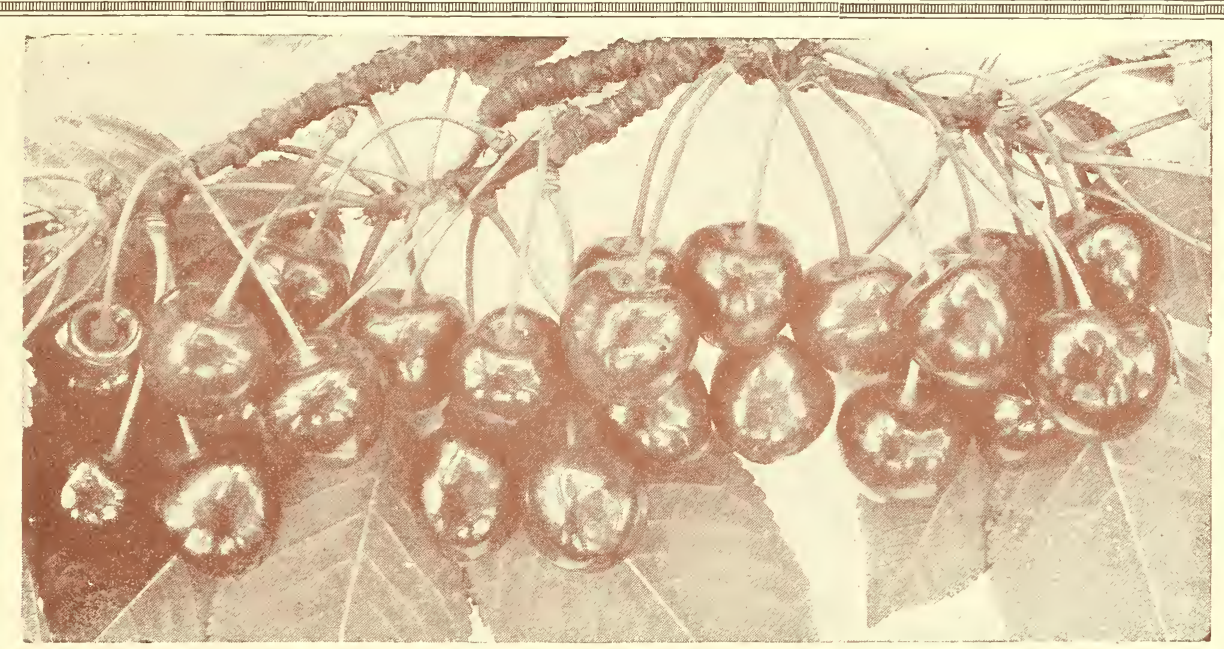

\section{Cherries}

There are few more desirable trees than the cherry, and they are being planted in larger quantities every year. No orchard is complete without its proportion of this fruit. It will succeed on any kind of soil that is dry.

The Heart and Bigarreau varieties do not succeed as well in the West and Southwest as in the East, but the Dukes and Morellos succeed everywhere. Cherries are now generally worked on the Mahaleb, a stock that does not throw up sprouts from the roots.

\section{Heart and Bigarreau Cherries}

Black Tartarian. Very large; bright purplish black; juicy, very rich, excellent flavor; half tender. Productive. Vig. First of June.

Governor Wood. Very large; light red; juicy, rich and delicious. Tree healthy and a great bearer. One of the most valuable varieties. Vig. First of June.

Napoleon. A magnificent cherry of the largest size. Pale yellow or red; flesh firm, juicy and sweet. Very productive. One of the best for market or canning. Vig. Middle of June.

\section{Duke and Morello Cherries}

Dyehouse. Resembles Early Richmond, but is of finer quality, quite as productive, and ripens a week earlier. It partakes both of the Morello and Duke, wood and fruit. Free. May and June.

English Morello. Medium to large; black. ish-red; rich, acid, juicy and good. Very productive. Mod. July.
Early Richmond. (Kentish; Virginia or Early May). The most hardy of all cherries, uninjured by the coldest winters when almost every other variety has been killed. Medium size; dark red; melting, juicy, sprightly acid flavor. Exceedingly productive. Unsurpassed for cooking and the most popular of the acid cherries. Free. First of .Tune.

Large Montmorency. A cherry of the Richmond class, but larger and more solid, and fully ten days later. Fruit red, acid. Free. Middle of June.

Wragg. Originated in Iowa. A variety much like English Morello, but larger, better and hardier. Medium to large, long stem; dark purple when fully ripe. Well adapted for the high latitude and prairie regions of the Northwest. July.

Compass Cherry. A cross between the Rocky Mountain cherry and the Native plum, and resembles both. The most remarkable fruit of recent origin. Hardy as any wild plum. Sweet, juicy and excellent flavor. Marvelously prolific bearer. Grows on any soil. Fruits every year. Bears second year after planting. Good shipper and a fine cooker.

\section{Grapes}

The grape is the most satisfactory fruit to raise and is at home in the West. Its history is almost as old as that of man. Vineyards were extensively planted before orchards or collections of other fruit trees were at all common, and today it is one of the most highly appreciated fruits. No fruit will give better returns for close attention and kind care, and good returns can be had from soils which are unfit for other crops. They 

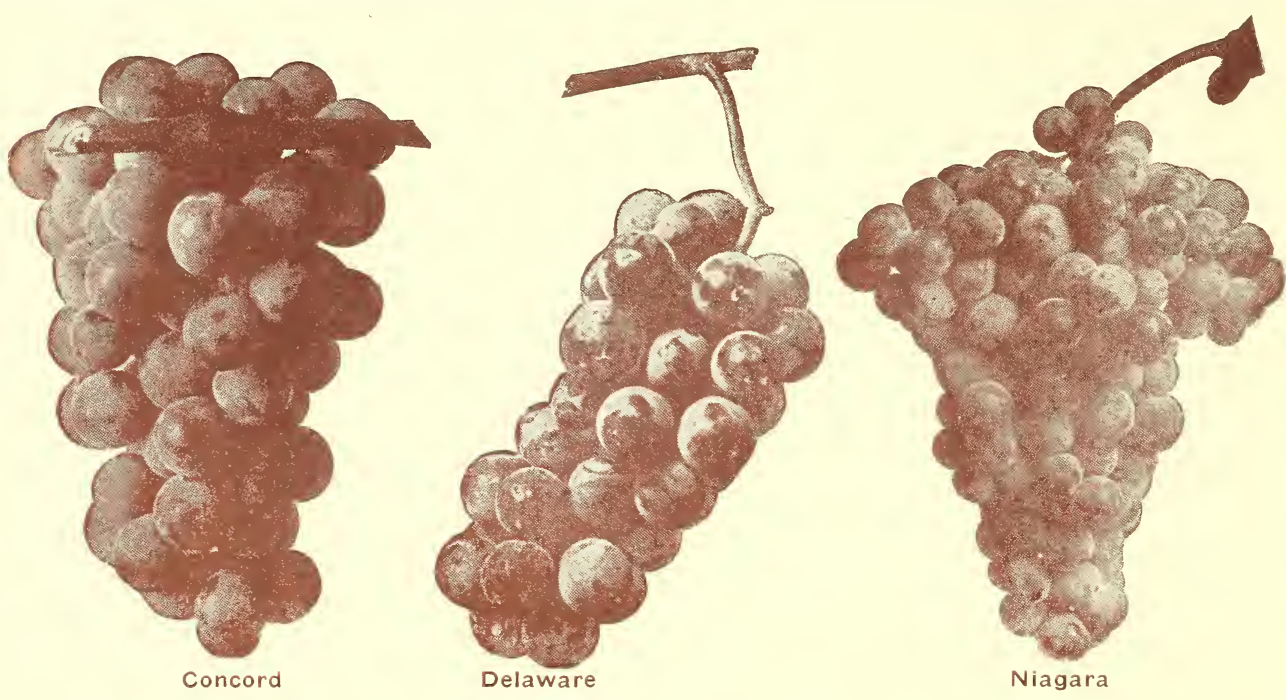

can be trained up the sides of any building or over a garden fence, but the best and cheapest way to grow them either in small or large quantities is on the wire trellis. Careful pruning is necessary for good crops, and should be done when the vine is entirely dormant.

Plant in rows 8 feet apart and 6 to 8 feet in the row, in deep, cultivated ground, and a little deeper than when in the nursery.

\section{Black Grapes}

Campbell's Early. The vine is strong, hardy and of vigorous growth, with thick, heavy, healthy foliage. Berries borne in large clusters, nearly round, large, of a glossy black color, with a beautiful blue bloom; pulp sweet and juicy; free from foxiness; seeds small, few in number, and parts readily from the pulp. Ripens with Moore's Early, but, unlike that variety, keeps sound and perfect for weeks after ripe. Valuable for shipping.

Concord. The most popular grape in America. Bunch and berries large, round; skin thick and covered with bloom; flesh juicy and sweet. The vine is very hardy, vigorous and productive.

Moore's Early. A Concord seedling. The entire crop ripens before its parent. Bunch medium; berries large, with blue bloom; flesh pulpy, of medium quality. The vine is hardy and moderately productive. Very profitable for market on account of its earliness and handsome appearance.

Worden. A splendid grape of the Concord type, but earlier; larger in bunch and berry, and of decidedly better quality. Vine as hardy, and in every way as healthy.

\section{Red Grapes}

Brighton. A cross between Concord and Diana Hamburg. Bunch large, well formed, berries of medium size; purple, flesh tender, sweet, of best quality. Ripens early. Showy for table or market.

Catawba. The famous wine grape. Bunches large and loose; the berries are large, of a coppery color, becoming purple when fully ripe. Ripens late.

Delaware. Conceded to be one of the finest grapes. The bunch is small, compact and shouldered; berries rather small; skin thin; flesh very juicy, without any hard pulp, with a very sweet, spicy and delicious flavor. The vine is moderately vigorous, very hardy and productive.

Woodruff Red. One of the hardiest Grapes; a rank grower and very healthy. Bunch and berry large, shouldered and attractive; sweet and of fair quality. Desirable for market. Ripens soon after Concord.

\section{White Grapes}

Moore's Diamond. Very hardy, healthy and vigorous. A white dessert grape, with a sweet, sugary taste. Ripens two weeks before the Concord.

Niagara. Occupies the same position among the white varieties as Concord among the black. Bunch very large and handsome, sometimes shouldered, compact; berries large, round, with a tough skin and of good quality, have not much pulp when fully ripe. The leading, profitable market grape. Ripens about with Concord. Succeeds well both in North and South, and is very largely planted by vineyardists. 


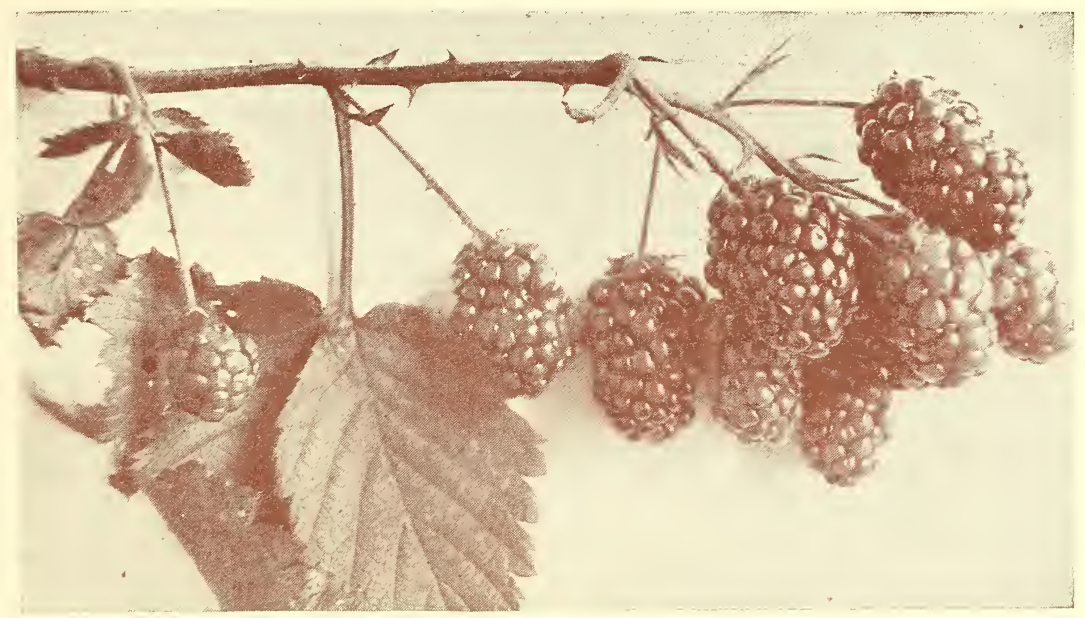

\section{Blackberries}

In field culture plant in rows 8 feet apart and 3 feet distant in the rows; in garden culture plant rows 5 feet apart and 3 feet distant in the rows. The pruning should be governed by the growth of the cane and should be severe. Pinch back the canes in summer when 3 feet high, causing them to throw out laterals.

Early Harvest. Very early and always reliable. A compact, dwarf grower.

Eldorado. One of the best blackberries for the North. Berries large, jet-black, borne in large clusters and ripen well together; very sweet, melting and pleasant; have no hard core, and keep from eight to ten days after picking with quality unimpaired. The vines are very vigorous and hardy. Enormous yielder.

Snyder. Medium size; no hard or sour core.
Extremely hardy and very productive, It leads where hardiness is a consideration.

\section{Dewberries}

Lucretia. One of the low-growing, trailing, blackberries. Fruit large, luscious and handsome. Perfectly hardy, strong grower and exceedingly productive. The vines give the best results when allowed to remain on the ground during winter and started up early in the spring.

\section{Raspberries}

The raspberry thrives on strong soil, well manured, thoroughly cultivated and mulched freely. For field rows, plant 6 feet apart and 3 feet in the row. In garden culture, tie up to single wire. Cut out the old and weak shoots each year. Raspberries may be made very profitable by good cultivation.

\section{Blackcaps}

Cumberland. The fruit is enormous, surpassing any other blackcap known. Is firm and will stand long shipments, mak. ing it a very profitable berry. The bush is very healthy and vigorous, and the hardiest and most productive in cultivation.

Gregg. The best late blackcap and very popular for market. Canes of strong, vig. orous growth, and under good cultivation very productive. Berries large, covered with heavy bloom, firm, meaty and of fine flavor. Requires good strong soil to produce best results. The standard blackcap by which others are judged.

Kansas. Originated at Lawrence, Kan. A blackcap which succeeds wherever tried. It is healthy, vigorous, not subject to leaf- blight, and produces strong, healthy tips; fruit large, very prolific.

\section{Red Raspberries}

Cuthbert. (Queen of the Market). Large, conical; rich crimson. The fruit is so firm that it can be shipped hundreds of miles in good condition. Flavor sweet, rich and luscious. Very strong and hardy, standing the Northern winters and Southern summers equal to any variety.

Ranere. Fruit commences to ripen with the earliest and continuing on young canes until October. Berries bright crimson, large size, rich sugary with full raspberry flavor. Flesh firm and meaty, a good shipper. Wonderfully prolific, the first or main crop equalling any red va. riety known. 


\section{Gooseberries}

This fruit is useful for cooking when green or ripe, and it may be canned with such facility that it is cultivated very extensively for both home use and market.

Manure heavily and prune closely to produce large, abundant crops. Close pruning and heavy mulching prevents mildew. Plant 3 to 4 feet apart each way.

Downing. Considered one of the most valuable varieties. Larger than Houghton, roundish; light green, with distinct veins; skin smooth; flesh rather soft, juicy and good. Vigorous and productive.

Houghton. A medium-sized American variety, which bears abundant and regular crops, and never mildews. Fruit smooth, red, tender and very good.
Carrie. Berries fair size, bright maroon color; excellent quality.

Champion (Oregon). Berries medium, round, smooth, greenish white with thin transparent skin, good quality; bush vigorous and very free from mildew.

Pearl. Similar to Downing, but fruit a little larger, hardy, free from mildew and very productive.

\section{Currants}

To get best results plant in a cool, sheltered, moist location about 3 feet apart in rows 4 feet apart. As they are perfectly hardy, they can be planted in the fall and are not injured by the cold winter weather. To destroy the curculio, dust with white hellebore when the dew is on the bush.

Cherry. The largest of all the red currants. Berries are very large; bunches short. The plant is very vigorous and productive when given good soil and cultivation.

Fay's Prolific. Deep red; first-class quality and not quite so acid as the Cherry; the stems are longer and the berries hold their size to the end of the stem better.

North Star. Bunches average 4 inches in length; the berries from a single bunch, thirty in number, placed side by side, touching, covered a line 12 inches long. Fruit sweet, rich and firm. Good for mar- liet, desirable for dessert in natural state and one of the best for jelly.

Perfection. This is a cross between Fay's Prolific and White Grape. Color red; as large or larger than Fay's and clusters average larger. Prolific.

Red Dutch. An old standard sort. A great bearer and very profitable for the inarket.

White Grape. The best table variety. Large, yellowish white; sweet or very mild acid; of excellent quality. Very distinct, having a low, spreading habit and dark green foliage. Very productive. The most valuable white sort.

Wilder. A remarkable variety both for table and market. Bunch and berry very large; bright, attractive, red color, even when dead ripe; hangs on bushes in good condition a long time.

\section{Strawberries}

The Strawberry is undoubtedly the queen of fruits. It is the first to ripen and the quickest to come into bearing. Those entering into field culture of strawberries for commercial purposes, without practical experience will hardly depend on the brief directions given here. Full instructions as to cultivation will be freely given upon application.

The Soil and Its Preparation. The ground should be worked 18 or 20 inches deep, and be properly enriched as for any garden crop; drainage is necessary in very wet soil.

Cultivation. For family use, plant 15 or 18 inches apart each way, and after a few strong plants have set from runners, then pinch off all runners as fast as they appear; keep the ground free of weeds, and frequently stirred with a hoe or fork. Plants treated in this manner will produce more crowns and yield therefore double the amount of welldeveloped fruit than when runners are left to grow.

Covering in Winter. Where the winters are severe, it is well to give the ground a light covering with coarse straw or litter. This covering should not be placed on until the 
ground is frozen. Fatal errors may be made by putting on too much and too early. If coarse straw is used, it may be left on until the plants have done fruiting, taking care to open it up around the plants early in the spring, so as to give them plenty of sunlight and air.

The blossoms of those marked with a letter (P) are destitute of stamens and are termed pistillate, and unless a row of perfect-flowering variety is planted at intervals not exceeding every third or fourth row, they will produce imperfect fruit and but little of it; but, when properly fertilized, as a rule, they are more prolific than those with perfect flowers.

Aroma. S. Very large, roundish, conical, rarely misshapen; glossy red, of excellent quality, and very productive. The plant shows no weakness of any kind.

Bederwood. S. Large, roundish, conical, bright scarlet; moderately firm, fair quality. The plant is vigorous and very productive. This is a very desirable early berry for either home use or near market.

Dr. Burrill. A marvel of productiveness, quality, color, size and firmness, which is seldom found in any one variety. The fruit is very firm and of even shape; dark, glossy red with yellow seeds and green calyx; making a beautiful combination.

Dunlap. S. Large and handsome; rich dark red, with glossy finish, shading to deep scarlet on under side. Uniform in size and shape.

Gandy. S. Large and firm; berries bright crimson, very uniform in size and shape.

\section{Everbearing}

Progressive. (P). This is probably the best everbearer of the entire lot. It is to everbearers what the Dunlap is to the June bearing varieties. It is a cross between the Dunlap and the old Pan American. The plant very much resembles Dunlap though it is not quite as thrifty

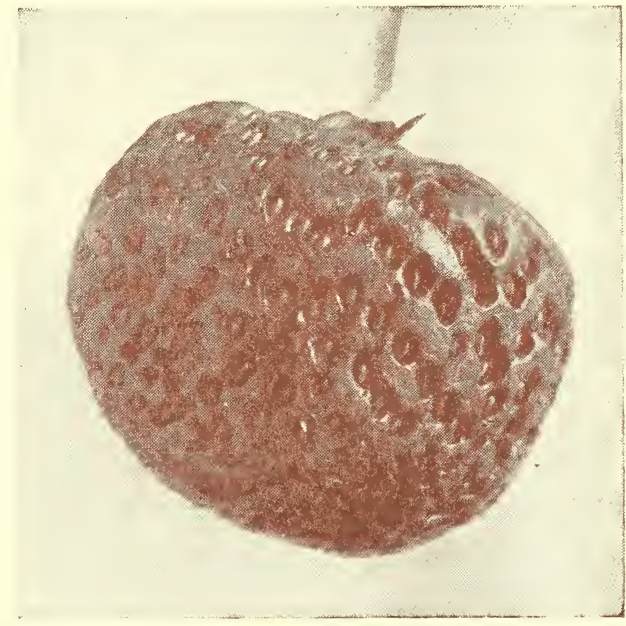

Senator Dunlap

Plant vigorous and healthy. A reliable and valuable late strawberry.

Gibson. One of the best and most profitable sorts for both home and market. Strong growers with long roots, abundant foliage, very productive. Berries extra large, choice flavored, dark glossy red.

Warfield No. 2. P. One of the most popular varieties today. Pleasant, sub-acid, good. The plant is a vigorous grower, with bright, healthy foliage. Early.

\section{Strawberries}

grower. It is hardy and withstands all kinds of weather. The foliage is very healthy.

superb. (P). This is the largest everbearing strawberry of them all. The berry is large, good color, even in size and holds. up well until the end of the season. It is a remarkable berry in every way.

\section{Asparagus}

This delicious vegetable should be found in every garden. Nothing can be more easily grown and no other plant will give so much good, healthful food for so little outlay.

Dig the soil deeply, and mix together with well-rotted manure or compost. Plant in rows 2 feet apart. The plants should not exceed a foot apart in the rows and planted about 4 inches deep. On approach of winter cover with manure and fork the beds over lightly in the spring.

Barr's Mammoth. A great favorite. A fine large sort, the stalks of which measure an inch in diameter, and retain their thickness nearly to the top.

Conover's Colossal. A mammoth variety of vigorous growth, sending up fifteen to twenty sprouts from 1 to 2 inches in diameter each year. The color is deep green and crown very close.

Palmetto. Earlier, a better yielder, more even and regular in growth than Conover's Colossal and equal in quality.

\section{Rhubarb}

Rhubarb ranks among the best early vegetables. It affords the earliest material for pies and tarts, continues long in use and is valuable for canning. Make the soil very rich.

Linnaeus. Large, tender and fine. Eally. The best of all.

Victoria. The most valuable for market on account of its gigantic growth. 


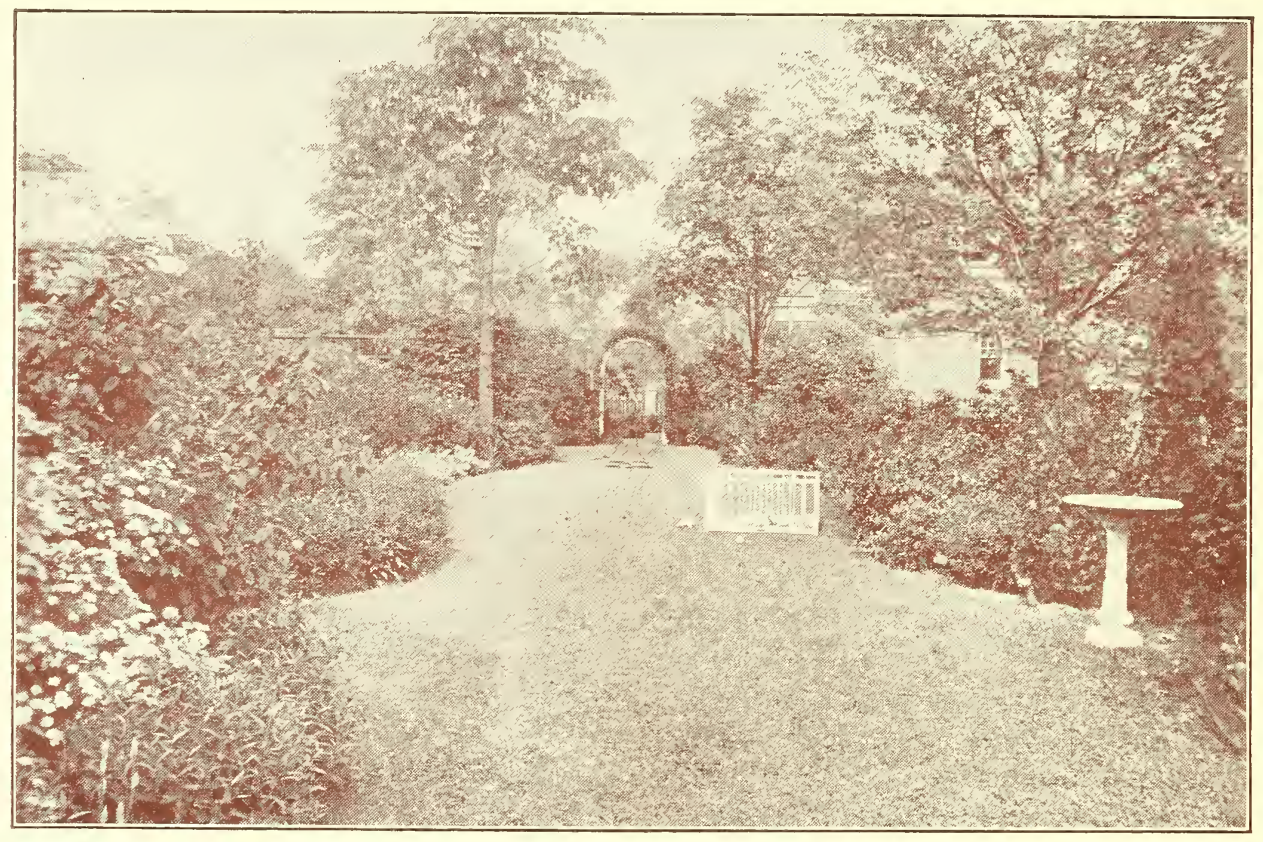

\section{Ornamental Department}

Suggestions to Planters. The extremes in temperature in this country are so great and the changes often so sudden that it is safe only to plant the most hardy ornamental trees and shrubs. Those varieties that will grow in the nursery when young without protection in winter may be regarded as safe to plant in parks and extensive grounds and in lawns and small places. Yet a few of the most beautiful sorts are not perfectly hardy and will be greatly benefited by some protection during severe winters. A judicious selection from the many varieties given in this catalog will enable the planter to accomplish his desire in securing that which will give him satisfaction, both in hardiness and in effect.

For Parks and Extensive Grounds. In making selections of trees for this purpose there can be no difficulty, as there will be places for some of all the popular strong-growing sorts as well as many places for the smaller and more ornamental varieties, which are frequently planted in groups, and when by a proper selection so that there may be a succession of flowering and a variety of coloring of the foliage in the autumn, they make a picturesque appearance. But it cannot be too strongly urged upon planters the importance and value of flowering shrubs for effective masses and groups. All the hardy varieties such as Altheas, Forsythias, Weigelas, Calycanthus, Deutzias, Snowballs, Hydrangeas, Lilacs, Syringas, Fringe (Purple and White), Almonds, Peonies, Phlox and many others, when arranged either in groups or properly distributed, produce a magnificent effect, and what grand masses of bloom can be had throughout the season by proper use of the various families. The purple and variegated-leaved trees and shrubs may also be planted in such a manner as to afford a rich and striking contrast.

For Lawns and Small Places. A little more care may be taken in making selections for this purpose, although the selections will depend very much on the size of the ground to be occupied. Where only a few trees and shrubs can be planted, the medium or smallgrowing sorts, and those that display the finest appearance both in foliage and flowers, should be used. While on larger places a more extensive assortment can be planted.

Evergreens. It is unnecessary to argue in favor of the planting of this noble species of ornamental trees. Their stately appearance has too often caught the eye of the admirer of beautiful landscapes, parks, lawns and home places and left its lasting impression on the mind to be forgotten or overlooked in arranging the planting of even small grounds. Nothing is more beautiful than a well-arranged group of select evergreens, and when properly distributed, singly over the grounds, their appearance adds greatly to the scenery. 
When and How to Plant, Prune, Etc. The same directions as are given in the front pages of this catalogue will apply to ornamental trees and shrubs. Little pruning is necessary on the Pines, Spruces, etc. It is necessary to shorten and thicken the growth and preserve the shape and this should be done just before the buds begin to swell in the spring. Arbor Vitaes, Junipers, Cedars, etc., can be shortened in or sheared any time during the growing season. Too much care cannot be taken to keep the roots of evergreens from being exposed to the atmosphere while out of the ground, and a protection the first year from the sun and winds by a lattice work of thin lath will aid in securing the life and growth of many evergreens.

\section{Deciduous Trees}

ASH, American White (Fraxinus Americana). A beautiful and desirable shade tree, also valuable for timber. It grows very rapidly.

BIRCH, European White (Betula alba). A beautiful tree, with white bark and graceful foliage. A graceful and hardy species of drooping habit. Desirable as single specimen or planted among other trees for contrast.

Purple-leaved (B. Alba purpurea). Has beautiful purple foliage, as dark as the Purple Beech. It is very desirable for the lawn.

BUTTERNUT or WHITE WALNUT (Junglans cinerea). A fine native tree, producing a large longish nut, which is sought after for its sweet and edible kernel. Fine for lawn or orchard planting.

CATALPA Bungei. A dwarf species when on its own root, and makes a curious, compact tree or shrub with a globular head, even more symmetrical than the Umbrella China tree of the South. Absolutely healthy and hardy; its branches are numerous and short, and the broad leaves lie as shingle on a roof, making a dense shade. It is very effective for lawn and terrace decoration.

Speciosa. Especially ornamental in June when laden with its profusion of white flower panicles. A strong, quick grower.

CHESTNUT, American (Castanea Americana). A large and beautiful well-known forest and nut-bearing tree. Few trees combine such vigor and grand stature, with so many other good qualities. Planted extensively for profit and ornamental purposes.

CRAB APPLE, Bechtel's Double-flowering (Malus Ioensis). The finest of the many beautiful varieties of the Flowering Crab Apples. Tree of medium size, covered in early spring with large, double, fragrant flowers of a delicate pink color, having at a distance the appearance of roses. It is without doubt one of the handsomest trees grown.

DOGWOOD, White-flowering (Cornus florida). A beautiful American species of fine form, growing from 16 to 25 feet high. The large, white flowers are produced in spring before the leaves appear. The leaves are green, turning to a deep red in autumn. Indispensable for lawn or landscape.

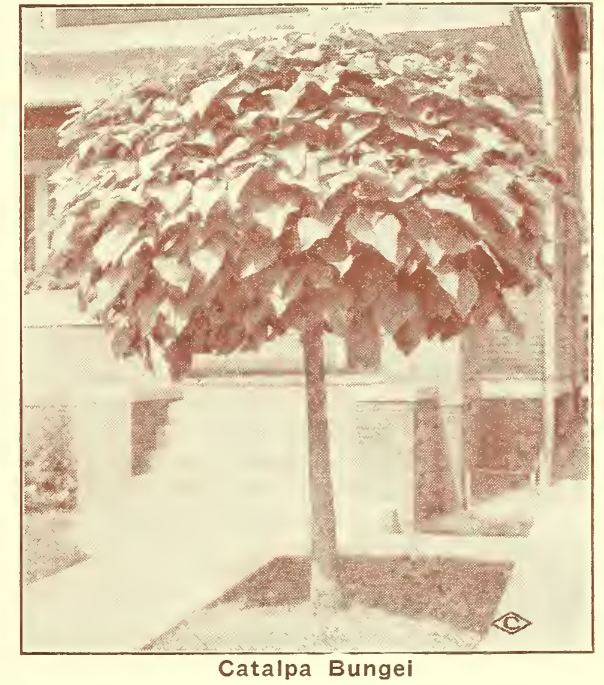

ELM, American White (Ulmus Americana). The most distinct tree adorning American landscapes. Fine for parks.

JUDAS TREE, or RED BUD, American (Cercis Canandensis). A small Western tree with a wealth of floral beauty in the spring before the leaves appear. Nothing can be more beautiful in April or May than a large, round-headed Red Bud, covered with its pretty flowers, before the bursting of a single leaf.

KOELREUTERIA paniculata (V a r nis h Tree). A small tree, with a handsome, round head, native of China. Fine lobed leaves, which change to a fine yellow in autumn, and large panicles of showy. golden flowers the last of July. A handsome tree and very desirable on account of its flowers coming when few trees are in bloom.

LIQUIDAMBAR styraciflua (Sweet Gum). One of the best of our native trees. Of. medium size, round-headed or tapering, with leaves somewhat resembling the maple, but are star-shaped and of a beautiful green in summer, changing to deep purple crimson in autumn; bark corky: Unsurpassed in beauty by any other tree. 


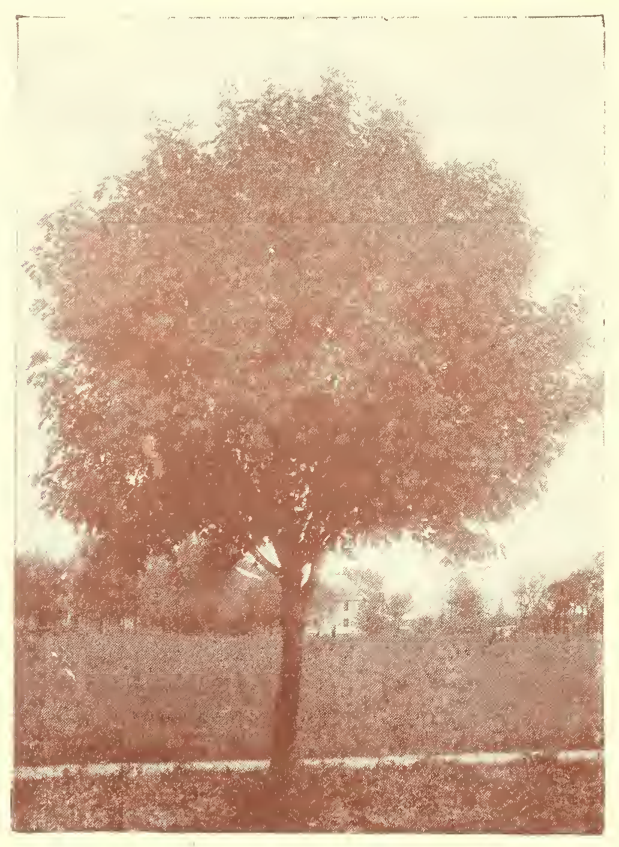

Hard Maple

LOCUST, Black or Yellow (Robinia pseudacacia). A large native tree of rapid growth, and valuable for shade or ornamental purposes. The white flowers are very fragrant and borne in drooping racemes in May or June.

Rose, or Moss. A native species of spreading, irregular growth, with long, elegant clusters of rose-colored flowers in June and at intervals all season.

MAGNOLIA, Soulangeana. A mong the hardiest and finest of the foreign Magnolias. Its blossoms are from 3 to 5 inches across, cup-shaped, white and rosy violet.

MAPLE, Norway (A. platanoides). One of the best ornamental trees for street, lawn, park or cemetery planting in cultivation. A foreign variety, with large, broad leaves of a rich, deep green color.

Schwedler's (A. Schwedleri). The young shoots and leaves of this beautiful variety are a bright purplish and crimson color, changing to purplish green when the leaves get older.

Silver-leaved (A. dasycarpum). This Maple may be seen along the street of almost every town or village. Of very rapid growth, hardy and easily transplanted.

Sugar, or Rock (A. saccharum). Much used for shade in lawn and park plantings. The tree is very stately and has fine foliage which has a brilliant autumn coloring.

Wier's Cut-leaved (A. Wierii laciniatum). A Silver Maple with beautiful dissected foliage. Of rapid growth; the shoots are slender and drooping, giving it a very graceful appearance. A great favorite and of deserved popularity.

OLIVE, Russian. An ornamental tree of special value, growing to a height of 30 feet or more. The bark and leaves are light green when young, the bark getting darker and the leaves more silvery white as the tree grows older. The blooms are in small racemes 3 inches long, with a sweet and spicy fragrance, and are borne profusely in June.

OAK, Pin (Quercus palustris). The most popular of all the Oaks. The foliage is deep green and finely divided; assumes a drooping form when it acquires age.

Red (Q. rubra). An American species of large size and rapid growth. Deeply cut green leaves. Makes a splendid lawn or shade tree.

Scarlet (Q. coccinea). Especially valuable for its brilliant scarlet fall color. Grows well in dry situations. Leaves are large and feathery.

PLUM, Purple-leaved (Prunus Pissardi). A handsome small tree, with purple foliage and black bark, and retains its color throughout the summer. The new growth is especially bright. One of the best of purple-leaved trees, the hot sun not affecting the leaves.

POPLAR, Bolleana. Similar to the wellknown Lombardy Poplar in habit, but broader, and like it, useful in breaking the monotony of lower round-topped trees. Will grow to a tall spire 80 feet high. Its leaves are glossy green above, silvery beneath.

Carolina ( $P$. Caroliniensis). This is the finest Poplar and more extensively planted in cities for quick effect than any other variety. Of good form and succeeds everywhere. Makes a splendid windbreak or screen, and is used in larger numbers than any other shade tree. Resists smoke and gas.

Lombardy (P. Nigra fastigata). A wellknown, tall, erect-growing tree of rapid growth and spire-like outline. Very desirable in landscape planting to destroy the sameness and give variety to the other trees. An avenue of this variety is a beautiful sight.

SALISBURIA adiantifolia (Maidenhair Tree or Ginko). A graceful and picturesque 
tree, with yellowish green leaves, curiously lobed and marked with delicate hair-like lines. A valuable ornamental tree, and useful for street and avenue planting, and is generally free from insects and diseases.

SYCAMORE, American Plane or Buttonwood (Platanus occidentalis). One of our tallest well-known trees. Valuable for planting in the city streets as it is remarkably free from diseases and withstands the smoky atmosphere.

TULIP TREE (Liriodendron Tulipifera). A magnificent native tree of the Magnolia species. A large and stately rapid-growing tree, with rich, glossy foliage. The flowers appear the first week in June and are large, tulip-like, with a greenish yellow color, blotched orange. Hard to transplant unless of small size. Plant only in spring and prune closely.

WALNUT, Japan (Sieboldi). perfectly hardy, rapid grower, handsome form, immense leaves; bears young and abundantly; one of the finest ornamental trees. Nuts produced in clusters; resembles Butternut in shape and quality; smaller; with smooth and thinner shell.

\section{Weeping Deciduous Trees}

Much attention is now given to this class of trees, and we place them separately for the convenience of our customers. The superior grace and beauty of the weeping varieties render them especially adapted to yard, lawn or cemetery. No collection is complete without them. Among ornamentals they have no superior.

BIRCH, Cut-leaved Weeping. (Betula laciniata pendula). A tall tree, with gracefully pendulous branches and deeply cut foliage. A superb lawn tree and very much admired.

MOUNTAIN ASH, Weeping (Sorbus aucuparia pendula). A beautiful tree, with straggling, weeping branches. A fine lawn tree and good for covering arbors.

MULBERRY, Teas' Weeping (Morus Tatarica pendula). A weeping variety of the now well-known Russian Mulberry. A graceful, hardy tree, forming a perfect umbrella-shaped head, with long, slender, willow branches drooping to the ground. The foliage is small, lobed and of a fresh, glossy green color. Very hardy and of rapid growth. Valuable for the cemetery and can be trained into almost any shape.

WILlOW, Common Weeping (Salix Babylonica). The well-known common Weeping Willow. A large tree, covered with drooping branches.

Wisconsin Weeping (S. Babylonica dolorosa). The leaves are whitened on the lower surface. Perfectly hardy, withstanding the winters of the far North without injury.

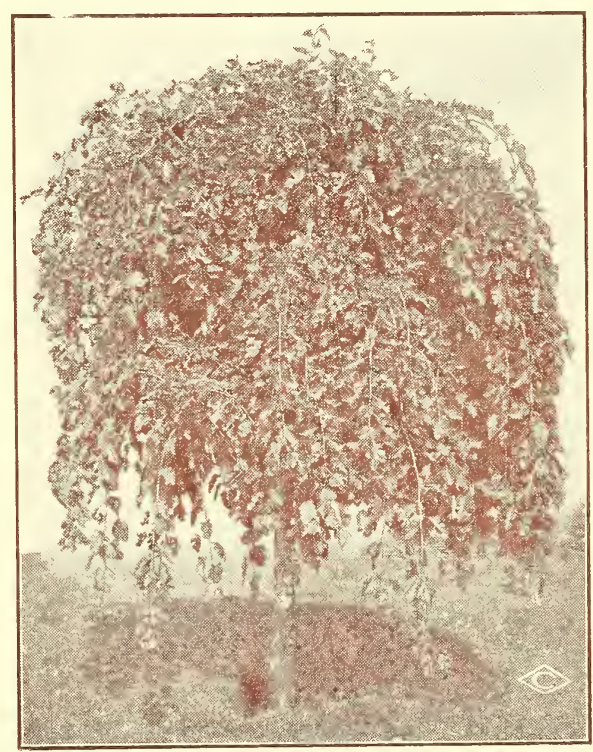

Weeping Mulberry

\section{Evergreen Trees}

ARBORVITAE, American or White Cedar (Thuya occidentalis). One of the finest medium-sized evergreens for screens or hedges. It is very hardy, there being very few places where it will not thrive. It bears shearing better than any other variety and may be made to grow into almost any desired form. More extensively planted than any other.
Compacta (T. occidentalis compacta). Upright, compact and very symmetrical; very hardy, retaining its beautiful green color all winter. One of the finest of the Arborvitaes.

Golden (T. aurea). A beautiful variety of the Chinese Arborvitaes. Compact and globular in form. Lively, yellowish green color. 


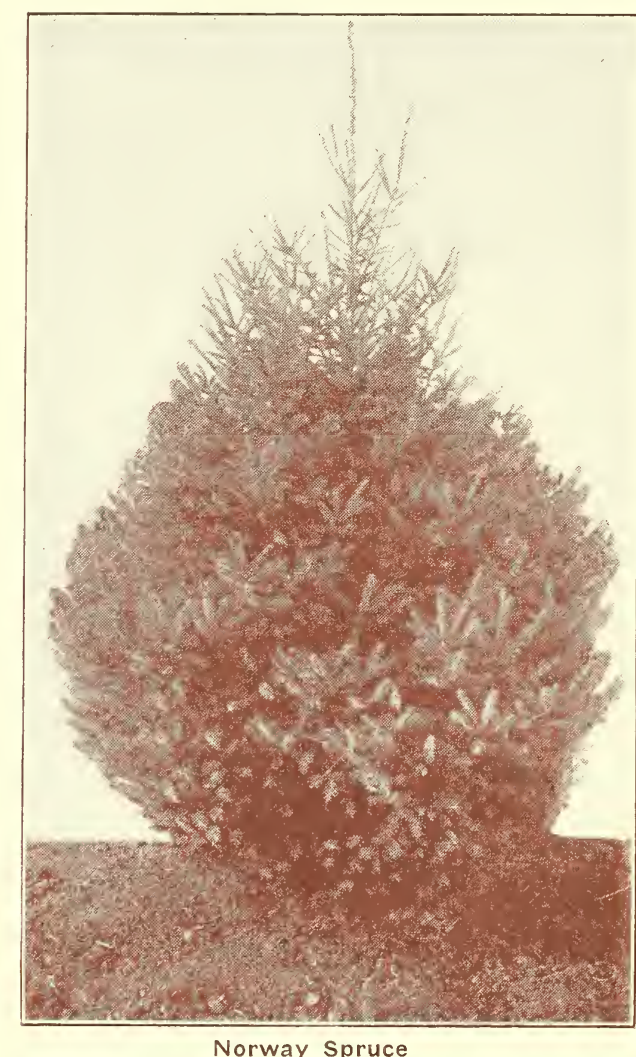

Norway Spruce

Globe (T. globosa). Originated at Philadelphia. Grows naturally into a rounded, almost ball-like form. Very desirable for grouping.

Pyramidal (T. Pyramidalis). Similar to the American, having dark green, compact foliage and very erect form. It is perfectly hardy. The most beautiful variety, and well adapted for formal planting and lawn specimens.

Siberian (T. Sibirica). One of the best of the genus. A slower grower and more compact than the American, of which it is a variety. The foliage is thicker, more luxuriant and retains its color well into the winter. Hardy.

FIR, Concolor (White Fir). A picturesque Colorado species; long, leathery leaves, with glaucous tinge when young, becoming pale green with age. Branches arranged in horizontal whorls. A grand tree, making splendid specimens.

JUNIPER, Virginian (Juniperus Virginana). This is the common well-known form of Red Cedar. It is usually compact and conical; very hardy and grows in unfertile places.
Glacious (Red Cedar). Is very desirable on account of its distinct, compact conical habit, and its silvery foliage.

Irish (J. Hibernica). Very erect in its growth, forming a dense, conical outline which resembles a pillar of green. Is very useful in formal plantings.

Pfitzeriana. One of the most striking of all evergreens, exceedingly useful for filling chinks in foundation plantings. The branches progress spirally along the trunk at a 45 degree angle, thereby making a good "filler"; or standing alone, it acquires the symmetry of a broken column. The branches are long and whip-like, densely furnished, very dark green; the first new growth thickly studding the expanse like silver beads.

Savin (J. Sabina). A low spreading tree, with dark green foliage. Very valuable for rockeries, groupings and borders, contrasting to other low-growing trees.

Tamariscifolia (Tamarix-leaved). A beautiful trailing form of Savin, with bluish green foliage.

PINE, Austrian, or Black (Pinus Austriaca). A tall massive species from the mountains of Syria; the branches are spreading, with long, stiff, dark green leaves. Very hardy.

Scotch (P. sylvestris). A native of the British Islands. Its rapid growth makes it suitable for screens and shelter-beds. Bluish foliage and ragged shoots. Thrives even on the poorest soils.

White (P. Strobus). A grand old favorite and the most ornamental of all our native Pines. The foliage is light, delicate or silvery green. It withstands hardships and grows in the most barren soils.

Mountain, or Dwarf (P. Mughus). Forms a dark, dome-shaped bush broader than its height and sometimes almost prostrate. Leaves short, stiff, a little twisted and thickly distributed over the branches. Fine for lawn specimens or evergreen groups.

SPRUCE, Norway (Picea excelsea). This familiar Spruce is more generally useful than any other variety. It is a lofty tree of pyramidal habit and very elegant and rich. With age it has fine, graceful, pendulous branches; very popular as an evergreen hedge. Is very picturesque and beautiful.

Colorado Blue (P. pungens glauca). This Spruce has been tested through the West and Northwest with perfect success, enduring a temperature of 30 degrees below zero in exposed situations without injury. It is also beautiful in color and outline, the foliage being of a rich blue or sage color. Makes an ornamental tree of great beauty. 


\section{Ornamental Shrubs}

ALTHAEA (Rose of Sharon; Hibiscus). Familiar shrubs and valuable because of their flowering in the fall when most other shrubs are out of bloom. Hardy and of easy cultivation.

Ardens. Double; violet; very large and distinct.

Boule de Feu. Very double; light rose; large. One of the finest red varieties.

Duchesse de Brabant. Double; reddish lilac flowers; large. A strong grower and one of the very best.

Jeanne d'Arc. Best of the double whites. Hardy and a free bloomer.

Pompon Rouge. Double, $3 \frac{1}{2}$ to 4 inches across; light rose. Is vigorous and fine.

Pulcherrima. Very large, double white, shaded pink; strong grower. One of the best.

Totus albus. Single; large, pure white.

Variegated-leaved Double Purple. Very showy and distinct. Leaves variegated with light yellow; flowers double, purple. very fine.

ALMOND, Dwarf Double Rose-flowering (Amygdalus communis rosea fl. pl.). A beautiful shrub, with small, double rosy blossoms closely set upon the branches before the leaves appear.

Dwarf Double White-flowering (A. communis alba fl. pl.). Same as preceding except that the color is white.

ARALIA Pentaphylla. Desirable for mass planting; slender, prickly branches; leaves palmate; five-lobed and pale green.

Spinosa (Hercules' Club). Valuable for producing tropical effects.

BARBERRY, Thunberg's (B. Thunbergii). An invaluable little shrub from Japan that fits in with almost every planting. Of dwarf, graceful habits; the foliage is small, changing to beautiful bright red early in the fall.

Box-Barberry. This new dwarf Barberry comes to fill a long-felt need for an edg. ing plant that is dwarf in growth, free from all diseases and insect pests, and absolutely hardy everywhere in the United States. The foliage is small and dainty. The young leaves are a beautiful emeraldgreen in the spring, changing to a pleasing soft green during the summer and rich red in the fall.

BUDDLEIA magnifica (variabilis magnifica). Deep purple-lilac flowers, borne in long, graceful panicles, commencing to open in midsummer and continuing until frost. The long, gray-green leaves add greatly to its beauty, and in every way it is a good addition to late-blooming shrubs.

CALLICARPA Purpurea. A pretty shrub from 3 to 4 feet high. It blooms profusely during August with small axillary clusters of pink flowers, these followed by berrybunches colored a light violet.

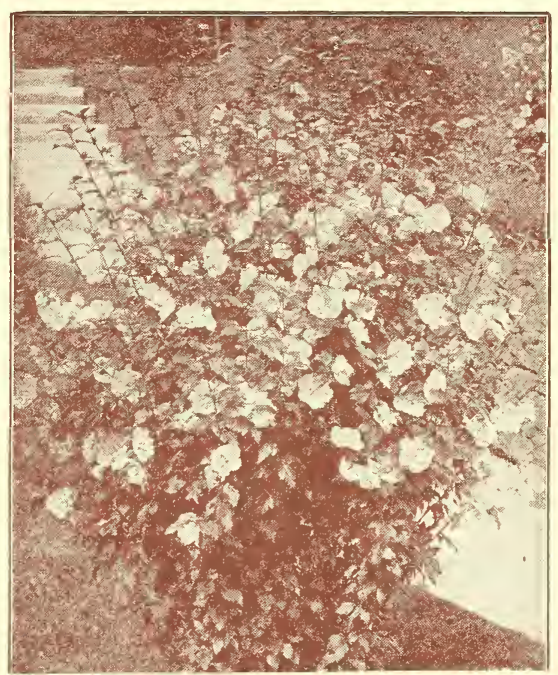

\section{Althaea}

CALYCANTHUS floridus (Sweet-scented Shrub). An old-fashioned shrub of strong, upright habit. The flowers and wood have a rare and peculiar fragrance; the blooms are borne abundantly and are of a chocolate color.

CARAGANA, arborescens. A very hardy, tall shrub, similar to the Laburnum in appearance, bearing pea-shaped, yellow flowers the first week in May.

CARYOPTERIS mastacanthus (Blue Spirea). A pretty shrubby plant, producing clusters of beautiful fragrant flowers in great profusion from September until frost. Valued for its lateness of flowers.

CURRANT, Crimson-flowering (Ribes sanguineum). Small, deep red flowers in long, drooping racemes in early spring. Is very ornamental.

Gordon's (R. Gordonianum). The flowers are crimson and yellow in pendent branches in May. Hardy and a profuse bloomer.

DEUTZIA gracilis (Slender-branched Deutzia). A dwarf species from Japan. The flowers are pure white. Fine for pot culture as it flowers freely at a low temperature in the winter.

Crenata fl. pl. Flowers double white, tinged with rose. One of the most desirable shrubs in cultivation.

Pride of Rochester. Raised from D. Crenata fl. pl., producing large, double white flowers, the back of the petals slightly tinged rose. The flowers are large, panicles longer and a more profuse bloomer than the older sort. Very vigorous.

Lemoinei. Without doubt one of the most important new hardy plants offered in 


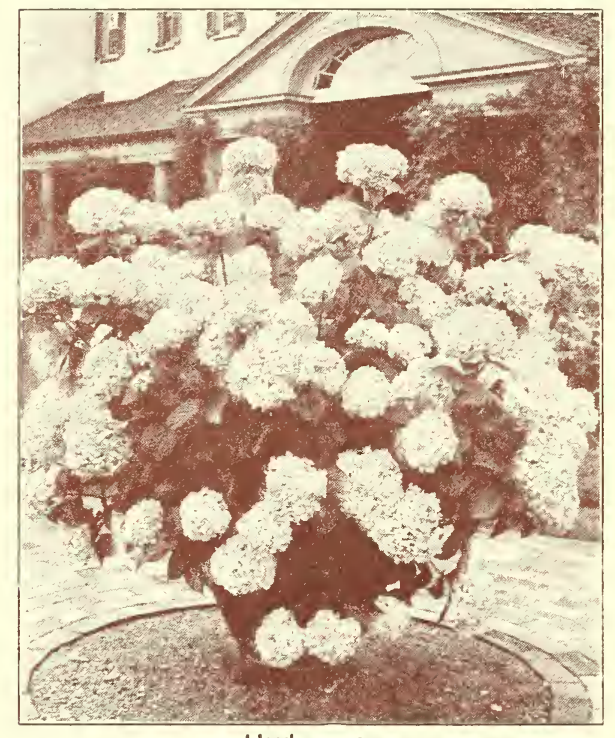

Hydrangea

many years. Large, pure white flowers, produced in broad-based, cone-shaped heads, which open out very full.

DESMODIUM Penduliflorum ( $\mathrm{L}$ e s p e d e $\mathrm{z}$ a Sieboldi). This is not really a shrub, being herbaceous, but it pushes up from the base so shrub-like that it is sometimes classed as one. Bears sprays of rosecolored flowers at a season when but few other shrubs are in bloom. Valuable for planting in beds or groups of shrubs.

DOGWOOD (Cornus Lutea). A striking yellow branched form of Stolonifera, very satisfactory for contrasting.

Stolonifera. A native species, with smooth, slender branches, which are usually red in winter, contrasting with the white fruit.

Red-branched (C. Siberica). The blood-red branches make it very conspicuous and ornamental in winter. The flowers are greenish white.

ELAEAGNUS angustifolia. A large shrub, sometimes of tree form, with long, narrow, silvery green foliage. The flowers are yellow, followed by yellow fruit.

ELDER, Golden (Sambucus nigra aurea). A handsome shrub, with golden yellow foliage and clusters of pure white flowers. Excellent for lawn planting.

EUONYMUS Americanus (Strawberry Bush). Very ornamental and showy, its brilliant dark red berries, which hang in clusters from the branches until mid-winter is its chief beauty. The contrast is very fine when planted with a background of evergreens. Leaves scarlet in autumn.

Europaeus (European Euonymus). A large, erect shrub, or low tree, sometimes 30 feet high; the fruit is rose-colored.
EXOCHORDA grandiflora. A vigorousgrowing shrub, forming a neat, compact bush, 10 to 12 feet high; flowers pure white, borne in slender racemes, of eight to ten florets each. Perfectly hardy. Unquestionably one of the floral genus.

FORSYTHIA (Golden Bell) virdissima. A large, hardy shrub, with dark green leaves and bright yellow flowers very early in spring.

Fortunei (Fortune's Forsythia). Of upright growth, with deep green foliage and bright yellow flowers.

Intermedia. Erect in growth, somewhat slender, very profuse in bloom.

Suspensa (Weeping Forsythia). Of graceful drooping habit; the flowers resemble those of Fortumei.

HONEYSUCKLE, Pink Tartarian (Lonicera Tartarica). An old-fashioned shrub, with bright pink flowers which appear in May, followed by crimson berries.

Jap. Bush Honeysuckle (L. Morrowi). A spreading variety growing 4 to 6 feet tall; blooms early in spring with pure white flowers, followed by pretty red berries.

Fragrant (L. fragrantissima). A spreading shrub, with deep green foliage and small fragrant flowers which appear before the leaves; the foliage is almost evergreen.

White Tartarian (I. Tartarica alba). Similar to the Red Tartarian, but with dull white flowers.

HYDRA N G A Paniculata grandiflora. From July to November there is no shrub more showy than this favorite Hydrangea. Its large, showy panicles of white flowers hang in the greatest profusion. It is quite hardy and very beautiful planted as a single specimen on the lawn or in the margin or masses. Prune severely in the spring to produce the largest flowers.

Arborescens grandiflora sterilis (Hills of Snow). Pure white, the flower-clusters remaining intact long after the leaves have fallen. Grows 5 to 6 feet high, and when in full bloom is one of the most striking as well as the most beautiful shrubs of its season.

KERRIA (Corchorus) Japonica. A slender green-branched shrub, 5 to 6 feet high, with globular yellow flowers from July to October.

Double-flowering Corchoras (Flora plena). It blooms profusely from the last of June until autumn, with double globular flowers.

LILAC, Persian (Syringa Persica). The lilac among shrubs is like the maple among trees. This variety is a native of Persia and grows from 4 to 6 feet high, with small foliage and bright purple flowers.

White Persian (S. Persica alba). White flowers delicately tinted with rose.

Large-flowering White (S. alba grandiflora). A beautiful variety, with large panicles of 
pure white flowers. Considered the best white variety.

Common (S, vulgaris). The well-known, old-fashioned lilac, so often seen in gardens. The flowers are bluish purple and very attractive.

Rouen (S. Rothomagensis). A distinct hybrid variety, with reddish flowers; the panicles are of great size and very abundant. One of the finest lilacs.

VARIETIES OF SYRINGA VULGARIS (LILAC)

Abel Carrier. Double flowers, large, blue, reverse of petals rose.

Charles $X$. Single. Strong rapid grower; trusses large, rather loose; reddish purple. Very popular.

Charles Joly. Double. Very dark reddish purple; superb.

Leon Simon. Double. Panicles compact; flowers bluish crimson.

Ludwig Spaeth. Single. Panicles long; individual flower large, dark purplish red. The finest of its color.

Marie Legraye. Single. Panicles of white flowers. One of the best.

President Grevy. Double. A beautiful blue; very large; the panicle is magnificent, measuring 11 inches in length and 5 inches across. One of the finest lilacs.

PLUM, Flowering (Prunus triloba). Semidouble flowers of a delicate pink, closely set along the slender branches, early in spring. A valuable addition to the early shrubs, and very ornamental.

PURPLE FRINGE (Smoke Tree; ; Rhus Cotinus). A shrub or small tree of spreading habit, covered in midsummer with a profusion of dusty, fringe-like flowers. Very much admired and desirable for the striking peculiarity of its flowers.

PRIVET, Common (Ligustrum vulgare). A tall shrub, with delicate foliage, white flowers in dense, upright panicles and bunches of black berries. In warmer climates it is evergreen the leaves hanging on very late. Valuable as a hedge plant.

California (L. ovalifolium). A large shrub of upright habit, nearly evergreen; produces delicate white flowers in great profusion; they possess a pleasant heliotrope fragrance. This is the most popular hedge plant.

Amoor (L. amurense). Erect habit; almost evergreen. More hardy than California.

Chinese (L. Ibota). Flowers large, white, very fragrant, produced in great profusion; the leaves are long and shining.

Regel's (L. Regelianum). S p r e a d ing branches. A prostrate form of the Chinese Privet.

PHILADELPHUS (Syringa or Mock Orange). All the species and varieties have white flowers, many of them quite

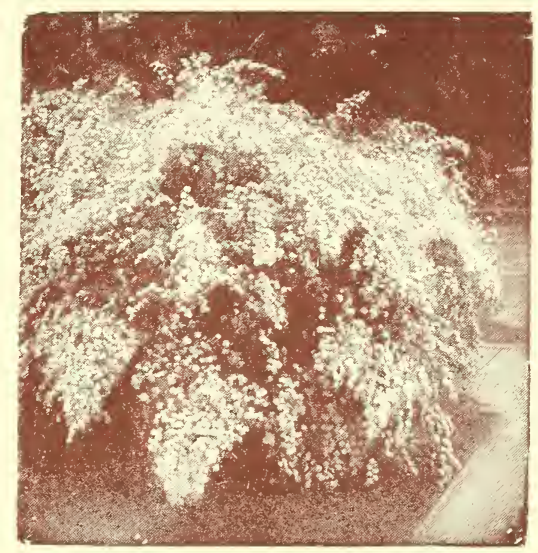

Spiraea Van Houtte

fragrant. They are vigorous growers and are very valuable for backgrounds, screens, groupings and specimens.

Coronarius (Common or Garland $\mathrm{Mock}$ Orange). A well-known, hardy shrub, with pure white, sweet-scented flowers. One of the first to flower.

Grandiflora (Large-flowered Mock Orange). Conspicuous and showy, with large flowers and irregular branches.

Lemoinei erectus. Upright growth; flowers fragrant, yellowish white, completely covering the plant.

RHODOTYPOS Kerrioides. From Japan. A medium-sized ornamental shrub, with handsome foliage and large, single white flowers late in May succeeding by numerous small fruits.

RHUS (Sumac) Cotinus. See Purple Fringe.

Canadensis (Fragrant Sumac). A spreading shrub; small yellow flowers in clusters or short spikes appear before the leaves; thick and fragrant foliage. In autumn the foliage turns to a dark crimson.

Glabra (Common Sumac). The foliage in autumn is a brilliant crimson, and the ovoid terminal panicles of fruit are bright purple.

Glabra laciniata (Dwarf Cut-leaved Sumac). Finely divided leaves, crimson in the fall.

Copallina (Mountain Sumac). A good species, with dark green, glabrous leaves. The branches and stalks are downy, and the leaf-stems are margined with wings.

Typhina laciniata (Staghorn Sumac). A large shrub, with brilliant foliage and scarlet fruit in autumn.

SNOWBERRY (Symphoricarpus racemosus). A small shrub, with clusters of rosecolored flowers, early in spring, followed by waxy white berries, which hang on 


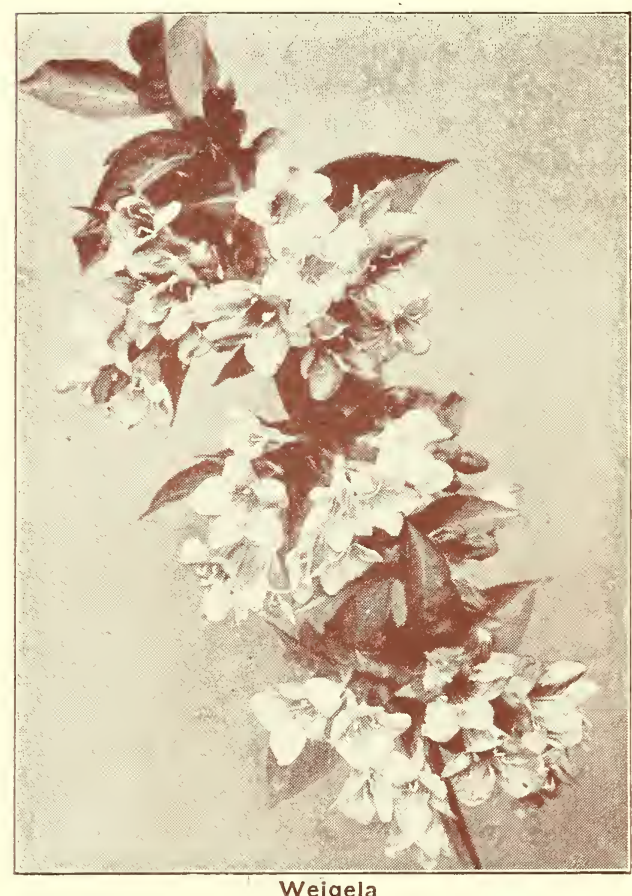

Weigela

through part of the winter. Quite hardy and very ornamental.

SPIRAEA Bumalda. A very handsome Japanese species of dwarf, compact habit. A mass of bright rose-colored flowers cover the plant during midsummer and autumn.

Arguta. It resembles somewhat S. Thunbergii but is of even more slender habit. In early spring it is a perfect mass of snow-white bloom on long, pendent branchlets.

Anthony Waterer. An improvement on Bumalda, forming a low bush 11/2 feet high, covered all summer with small flat heads of bright pink or solferino flowers. Beautiful for edging and desirable in front of shrubbery.

Billardi (Billard's Spiraea). Erect branches, crowned with narrow, dense spikes of rosecolored flowers nearly all summer.

Callosa alba (Fortune's Dwarf White Spiraea). All summer there are white flowers in flat clusters on this bushy shrub. Dwarf habit.

Froebeli. Dwarf, and similar to A. Waterer, but a trifle taller than the type, with broader leaves. Bright crimson corymbs during July and August.

Prunifolia (Plum-leaved Spiraea). Flowers white and very double, like English daisies, which bloom profusely in April. The foliage turns a beautiful bronze color in autumn. An old-fashioned erect shrub that is still popular.
Reevesiana, or lanceolata (Lance-leaved Spiraea). Narrow pointed leaves and large, round clusters of white flowers that cover the whole plant.

Thunbergii (Thunberg's Spiraea). A graceful bush, with innumerable small white flowers; leaves narrow. Valuable for forc. ing. Very early flowering.

Van Houttei. Among the very finest of flowering shrubs and the most charming and popular Spireas. It has pure white flowers an inch in diameter, in clusters or panicles. The profusion of bloom weighs the slender branches down and covers the bush with a canopy of white. The plant is remarkably vigorous and hardy. Excellent as a single plant or for grouping.

Opulifolia aurea. Golden yellow tinted leaves and double white flowers in June. A very conspicuous and valuable variety.

TAMARIX, Africana. Small leaves somewhat like the Juniper, and delicate, small pink flowers in spikes in May. Very ornamental at the back of shrubbery.

Gallica. Delicate pink or white flowers in slender panicled racemes; leaves bluish green.

VIBURNUM Lantana. A large, robust shrub, with soft, heavy, lantana-like leaves and large clusters of white flowers in May, succeeded by red fruits; retains its foliage very late.

Opulus (High-Bush Cranberry). Its red berries, resembling cranberries, hang until destroyed by frost late in the fall. Flowers white in drooping flat cymes.

Sterilis. The old-fashioned Snowball. Of large size, with globular clusters of white flowers in June.

VITEX Agnus-castus. Blue flowers. Blooms through August and September. Is valuable on account of blooming when so few flowers are in bloom.

Alba. White flowers.

WEIGELA Desboisi. Deep rose-colored flowers, resembling Rosea, but much darker.

Eva Rathke. The very best red-flowered variety. A continuous bloomer.

Rosea. A strong grower and profuse bloomer. Flowers pink, rose and white. May and June.

Van Houttei. Dark rich crimson flowers in great abundance; darker than Desboisi.

WHITE FRINGE, Virginian (Chionanthus Virginica). A large shrub that grows easily and is generally desirable. Superb foliage and delicate fringe-like white flowers in open clusters, succeeded by small bluish plum-like fruits.

XANTHOCERAS sorbifolia. A very popular new shrub. The flowers are white, with crimson center, and expand about the middle of May. It should be severely pruned when transplanted. 


\section{Hardy Climbing Vines}

AMPELOPSIS Tricuspidata (Boston Ivy;). The most popular ivy for covering buildings and walls. The foliage is smaller than the American and more dense, forming a sheet of green. The plant is a little tender when young and should be protected the first winter; when once established, it grows rapidly, the tendrils holding tenaciously to any support. The foliage changes to crimson in fall, which makes it a very beautiful ornament to a brick or stone structure.

Englemanni. Choice variety, with small, glossy green foliage, and disk-like tendrils, which enable the vines to attach themselves to stone and woodwork. Particularly desirable where the Boston Ivy is not sufficiently hardy, or where a more rustic effect is desired.

Quinquefolia (Virginia Creeper). A native variety of rapid growth, with large, luxuriant foliage, which assumes a beautiful rich crimson color in autumn. The inconspicuous blossoms are succeeded by handsome dark blue berries. The vine is supposed to take the place of the English Ivy, and in summer is not inferior to that variety.

BIGNONIA radicans (Scarlet Trumpet flower). Our well-known native species, with clusters of large trumpet-shaped scarlet flowers in August.

CELASTRUS scandens (Bittersweet; Staff Tree). A well-known native climber of powerful growth; the foliage is bright and shining. Is quite ornamental in winter on account of its orange-scarlet seed vessels, displaying their crimson seeds. Should be largely planted, as it is one of the most luxuriant climbers grown.

CLEMATIS Henryi. Large, pure white, handsome flowers. One of the best long bloomers among this class of climbers.

Jackmani. This is the most popular largeflowering variety. The flowers are from 4 to 6 inches in diameter, of an intense violet-purple color, borne successionally in continuous masses on the summer shoots. Generally considered the best Clematis of its color.

Mme. Edouard Andre. A great novelty. Flowers large, of beautiful bright velvety red; very free-flowering and continue all summer.

Ramona. A strong, rampant grower and very hardy. A free and perpetual bloomer of very large, deep sky-blue flowers.

Paniculata (Sweet-scented Japan Clematis). A Japanese plant possessing unusually attractive merits. Of very rapid growth, quickly covering trellises and arbors with handsome, clean, glossy green foliage. The flowers are of medium size, pure white, borne in immense sheets and of a most delicious fragrance. The flowers appear

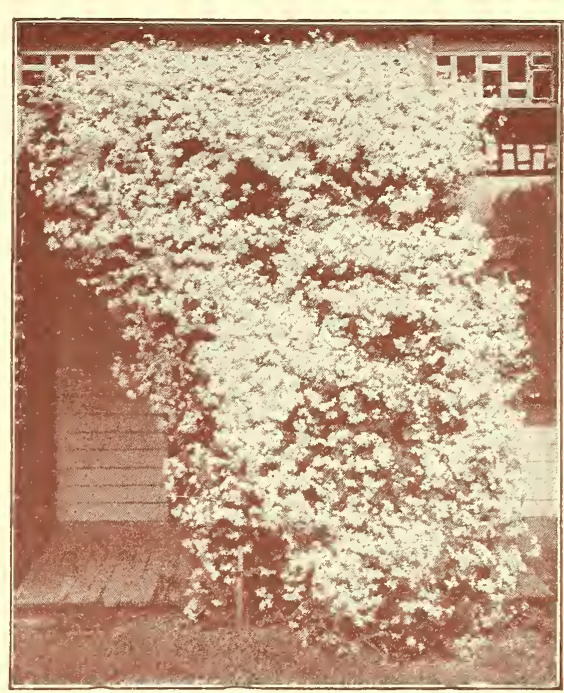

Clematis Paniculata

in September, a season when very few vines are in bloom.

HONEYSUCKLE, Monthly Fragrant (Lonicera Belgica). Very sweet, red and yellow flowers all summer.

Chinese Twining (L. Japonica). Blooms in July and September and is very sweet. Holds its foliage nearly all winter.

Hall's (L. Halleana). The most popular variety. Nearly evergreen. The flowers are pure white, changing to yellow, produced abundantly and have the fragrance of the jessamine. Probably more grown than any other variety.

Scarlet Trumpet (L. sempervirens). This and its varieties are the handsomest in cultivation. A strong, rapid grower, producing scarlet, inodorous flowers all summer.

POLYGONUM AUBERTI (Silver Lace Vine). This is the latest addition to our list of practical hardy vines, a quick-growing type of twining habit averaging 25 feet in a season. The small, cordate foliage is fresh and shiny. Produces more bloom than any other hardy vine, covering a season extending from late summer into the fall with an extravagance of large, foamy sprays in silvery white.

VINCA Minor (Common Periwinkle or Blue Myrtle). Evergreen verdure and handsome blue flowers. Compact, creeping habit, forming a solid covering.

WISTARIA, Chinese (Wistaria Sinensis). A rapid-growing, tall vine, with handsome foliage and flowers, which are produced in long, pendulous clusters of a pale blue color. It is very hardy and one of the most superb vines ever introduced.

American White. A native seedling with pure white flowers on short bunches. A free bloomer. 


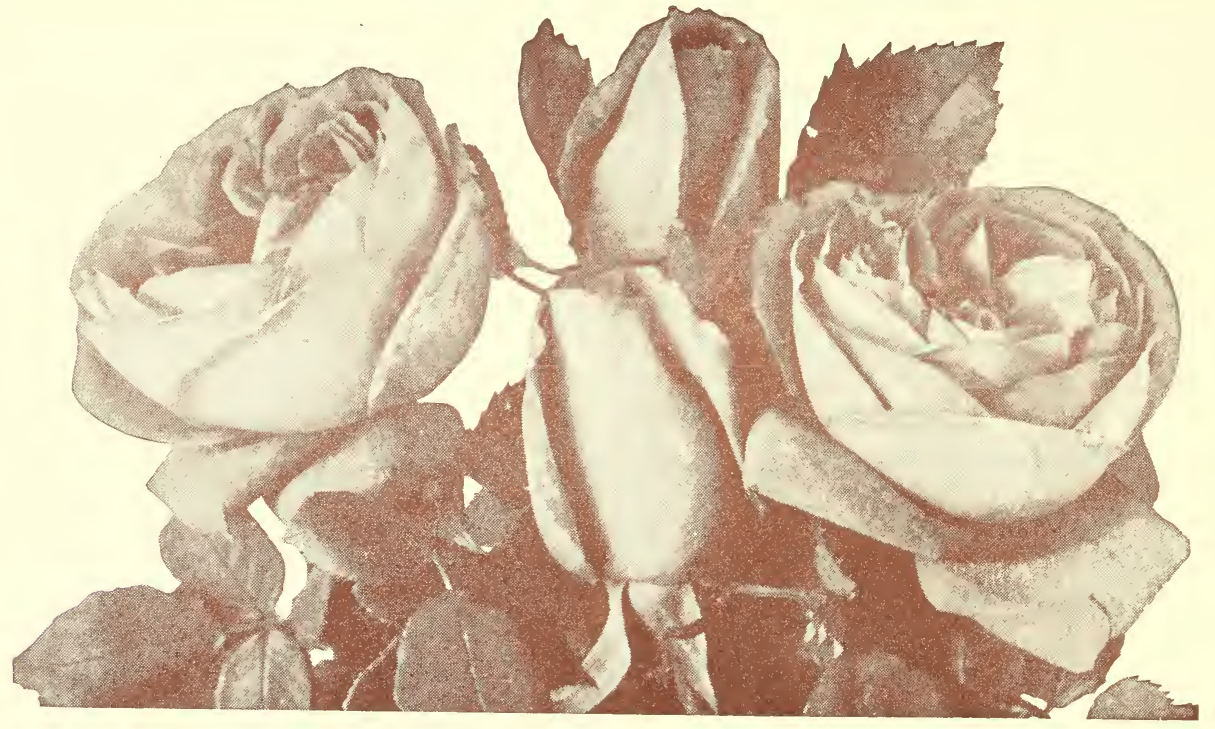

\section{Roses}

\section{Hybrid Perpetual, or Remontant Roses}

The Hybrid Perpetual Roses comprise the roses for the multitude. They are mostly hardy, vigorous and of easy cultivation. As a general rule, they thrive best in well-prepared loam. Close pruning is generally required, but should be regulated to some extent by the rate of growth of each variety, those of vigorous habit not requiring so much as those of slow growth. The colors range from the purest white to the deepest crimson. The term perpetual might lead some to think that they are as constant bloomers as the everbloomers, but this is not the case. They flower freely in June and at short intervals during the summer and fall.

Remedy for Mildew. The mildew is perhaps the most injurious disease. It is generally caused by extremes of heat and cold, and by a long continuance of damp, cloudy weather. The best remedies are sulphur and soot; one of these should be applied as soon as the disease makes its appearance. It is a good plan to sprinkle the plants with water so that the substance applied will adhere.

American Beauty. An everblooming hybrid perpetual. The flowers are very large, of beautiful form and very double; deep rich rose color. Its fragrance resembles La France. This is the most popular rose grown.

Clio. The flowers of this magnificent rose are perfect in form, with fine, broad petals. The color is a delicate satin blush, with a light shading of rosy pink at the center. Very free-blooming and a strong, healthy grower. The flowers are very beautiful at all stages of development.

Conrad Ferdinand Meyer. This rose has Rugosa blood in its make-up and is classed by some as a hybrid Rugosa; the best hybrid perpetual ever known. This is a grand rose, a vigorous grower, and free bloomer; flowers large, perfectly double, cup-shaped. Color deep, bright vivid, in. tense pink, with the penetrating fragrance of the old June roses.

Coquette des Alps. White, lightly shaded with carmine; of medium size; a free bloomer.

Frau Karl Druschki. Pure paper-white, large and free-flowering. A very handsome plant with bright, heavy foliage and strong upright growth. The bloom is of perfect form, on fine long stems. The finest rose in color, form and general finish.

F. J. Grootendorst. A wonderful new Hybrid Rugosa, being a cross between the Rosa Rugosa and the dwarf Crimson Baby Rambler. Undoubtedly the most beautiful of this class, possessing the true Rugosa foliage and producing large clusters of Crimson Baby Rambler flowers the entire season. Adapted for planting in masses, hedges or isolated specimens on the lawn.

General Jacqueminot. Crimson-scarlet; very showy and effective. A magnificent variety.

Hermosa. Beautiful clear rose; very double and fragrant, blooming in clusters; hardy and a constant bloomer. One of the best roses.

J. B. Clark. The color is unique among roses, being deep scarlet shaded blackish- 
crimson, with a rich bloom like a plum; flowers are large and beautifully formed.

Mme. Chas. Wood. Flowers extra large, full and double, of a deep rosy crimson color, sometimes brilliant scarlet, with maroon shadings. It blooms soon after planting out and continues all summer. One of the most beautiful hybrid perpetual roses.

Magna Charta. Prized on account of its strong, upright growth and bright, healthy foliage, and magnificent bloom. Beautiful bright pink, suffused with carmine. A general favorite.

Mrs. John Laing. A splendid rose, perfectly hardy, with immense flowers; full and double; borne in great profusion. Color clear bright shining pink; exquisitely shaded. Cannot be too highly recommended.

Paul Neyron. Deep rose color; good foliage. The largest rose in cultivation. Free bloomer.

Prince Camille de Rohan. Deep velvety crimson; large, moderately full. A splendid rose.

Ulrich Brunner. Raised from Paul Neyron. Brilliant cherry red-a very effective color; flower of fine form and finish. Plant vigorous, hardy and resists mildew. One of the best varieties.

\section{Moss Roses}

The beauty of this type of roses consists largely in the delicate mossy covering surrounding the bud. Some of them blossom in the fall and are called "Perpetual Moss." Perpetual White. Pure white; blooms in large clusters.

Princess Adelaide. Blush, becoming quite pale; very double and well formed. The most vigorous grower of the class.

\section{Climbing Roses}

American Pillar. A single-flowering variety of great beauty. The flowers are of enormous size, three to four inches across, of a lovely shade of apple-blossom pink, with a clear white eye and cluster of yellow stamens. These flowers are borne in immense bunches. They last in perfection a long time, and are followed by brilliant red hips or berries, which are carried late into the winter; and as the plant frequently retains its lovely green foliage until the end of December, it forms a beautiful decorative subject throughout the autumn months.

Baltimore Belle. Pale blush, almost white. Very beautiful and fragrant.

Climbing American Beauty. A seedling from American Beauty with Wichuraiana and Tea blood in its veins. The introducers say of it: "Same color, size and fragrance as American Beauty, with the addition of the climbing habit. Good foliage, and better blooming qualities. One plant of this new rose will produce twenty times as

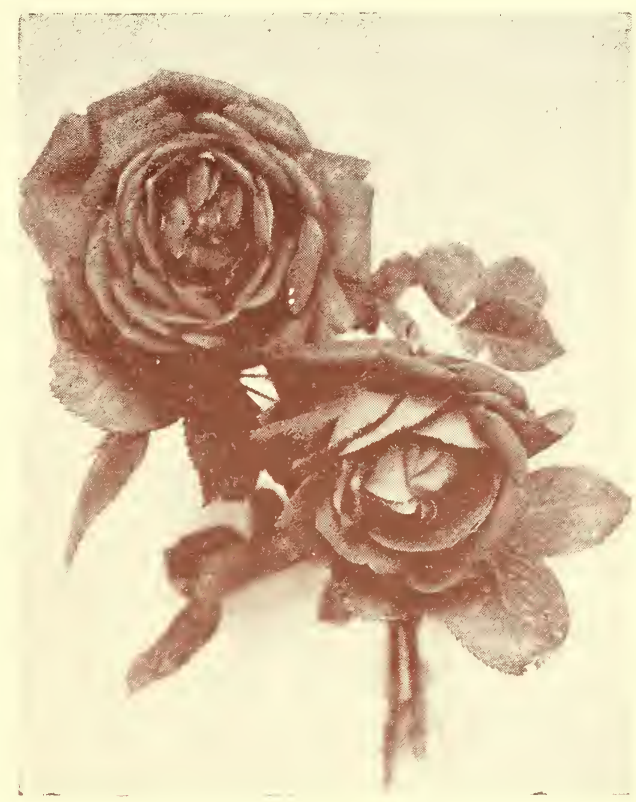

Gen, Jacqueminot

many flowers in June as the old American Beauty, besides blooming occasionally during the summer. Blooms three to four inches across; has proved perfectly hardy and stands heat and drouth as well as any rose."

Crimson Rambler. This charming climbing rose is unquestionably an acquisition. It is of vigorous habit, strong and rapid grower, with handsome, shining foliage, and produces in great abundance clusters of the brightest crimson semi-double flowers. Its showy clusters, abundance of bloom and length of time the flowers hang on the plant without losing their brilliancy are qualities which make it a favorite. As hardy as the Prairie Queen. Very desirable for verandas, walls, pillars and fences.

Dorothy Perkins. This rose is of the same strong habit of growth as the Crimson Rambler, the flowers being borne in clusters of 30 to 60 . The flowers are large for a rose of this class, very double, sweetly scented, and of a beautiful shell-pink color. Absolutely hardy.

Dr. W. Van Fleet. A delicate shade of flesh. pink, deepening to rosy-flesh in the center. High center petals beautifully undulated and cupped; buds pointed; flowers full and double, open to an immense diameter; sweetly perfumed; beautiful bronze green foliage.

Excelsa. A radiant, blood-red cluster rose, as free and double as Dorothy Perkins, of which it is the colored prototype. The 


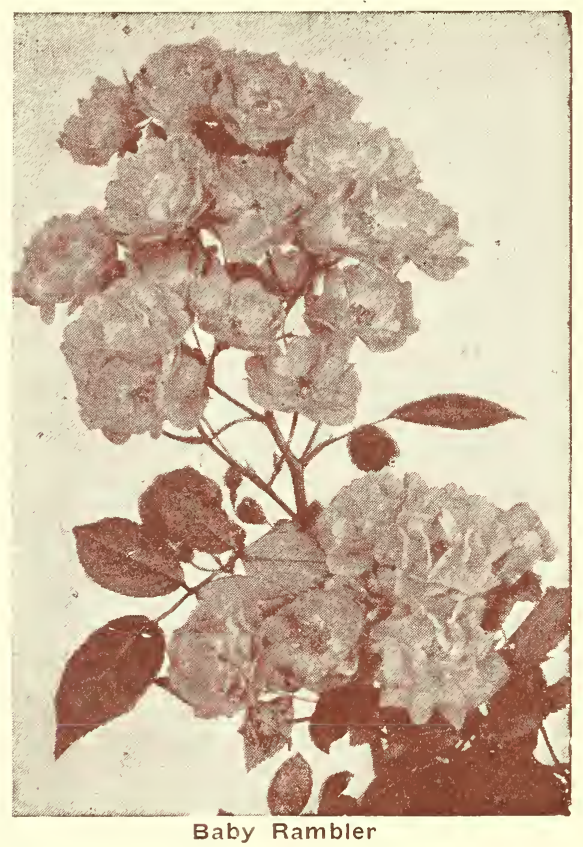

clusters are very large and fairly cover the vines.

Greville or Seven Sisters. Purplish crimson and pink.

Hiawatha. There is no other rose so brilliant as Hiawatha. Its flowers are about one and one-half inches across, and produced in long, pendulous sprays, with frequently from forty to fifty flowers on a spray. In color it is brilliant, ruby-carmine, with a clear white eye and a mass of golden stamens. The plant is of strong, vigorous growth, with bright green, glossy foliage, which is retained until late in fall.

Paul's Scarlet Climber. Vivid s c arlet, shaded crimson, makes a brilliant display for a long period of time in the garden. A wonderful new climbing rose. Received the gold medal and cup for the best new climber at the National Rose Society's exhibit.

Queen of the Prairie. Bright rose; large and double. Very vigorous.

Tausendschon (Thousand Beauties). A rapid growing, almost thornless climber, showing the blood of Rambler, Polyantha and Tea parentage. Its innumerable flower clusters make a pretty show through June and July; at first, the soft pink of Clotilde Soupert, and later deepening to a bright carmine rose.

White Dorothy Perkins. A white flowered form of Dorothy Perkins, very free of bloom. It has no rival as a white climber.

\section{Hybrid Tea Roses}

Etoile de France. A wonderful red variety that is becoming more popular each year. Will succeed in all parts of the country. The large blooms are a soft, velvety crimson on the outer petals and shading to a vivid cerise toward the center. Very double and sweet scented.

Gruss an Teplitz. Bright crimson, fiery-red center; cup-shaped; semi-double; flowers in clusters; so free in bloom as to present a blaze of scarlet.

Kaiserin Augusta Victoria. Pure white, with shadings of primrose-yellow, deeper in the center; a distinct and very beautiful variety.

Killarney. The finest pink forcing rose ever introduced. In coloring it is especially beautiful, being an exquisite shade of deep seashell-pink. The buds and flowers are of enormous size, the petals being frequently two and one-half inches deep.

Maman Cochet. This is the famous Pink Cochet. Light pink shaded with salmonyellow, outer petals splashed with bright rose; extremely large and full; fine for cut flowers.

Mrs. R. G. Sharman Crawford. Clear rosypink; the outer petals shaded with pale flesh; one of the very finest roses grown.

Richmond. Pure rich scarlet, a seedling from Lady Battersea; very free and continuous flowering, splendid forcer.

Jonkheer J. L. Mock. The blooms are of largest size, highly perfumed. Color clear imperial-pink.

Los Angeles. Originators' description: "Los Angeles is, by all odds, one of the finest roses ever introduced. The growth is very vigorous, and produces a continuous succession of long-stemmed flowers of a luminous flame-pink toned with coral and shaded with translucent gold at the base of the petals. The buds are long and pointed and expand into a flower of mam. moth proportions, while the beauty of form and ever increasing wealth of color is maintained from the incipient bud until the last petal drops."

Madame Caroline Testout. Clear bright satiny-pink; flowers very large and extremely showy.

Ophelia. Salmon-flesh shaded with rose, large, and of perfect shape; of excellent habit, the flowers standing up well on long, stiff stems and produced in great profusion.

Radiance. Brilliant rosy-carmine shaded with rich opaline-pink tints in the open flowers, which is large, full, of fine form, with cupped petals; a constant bloomer, producing strong, upright canes and an excellent keeper in summer.

Red Radiance. A bright, cheerful and even shade of pure red. Size, foliage, growth and habit same as in the parent "Radi- 
ance"; a splendid bloomer and fine variety for outdoor planting.

Sunburst. This magnificent giant yellow rose is a fine forcer; it stands head and shoulders above all others of its color, and will rank with American Beauty and the

\section{Miscellaneous Hardy Roses}

Harrison's Yellow. Bright yellow; double. Very showy and fine.

Hugonis. New Yellow Chinese Briar. Flowers single, flat to cup shaped, their color is bright and noticeable, ranging in shades of yellow from deep gold to canary. A matured bush may attain a height of 6 feet with corresponding spread. Very hardy.

Persian Yellow. Deep golden yellow flowers of medium size. Double, and very fine.

Rugosa alba. A splendid single white variety. Highly scented.

Rugosa rubra. Bright rose-crimson. The flowers are succeeded by red berries. A very handsome shrub.

Setigera (Prairie Rose). Single deep rose-
Killarneys in value and grandeur. The color is orange-copper or golden-orange and golden-yellow; edge of petals lighter; all intense shades, extremely brilliant in effect. It is the yellowest of all roses in the everblooming class.

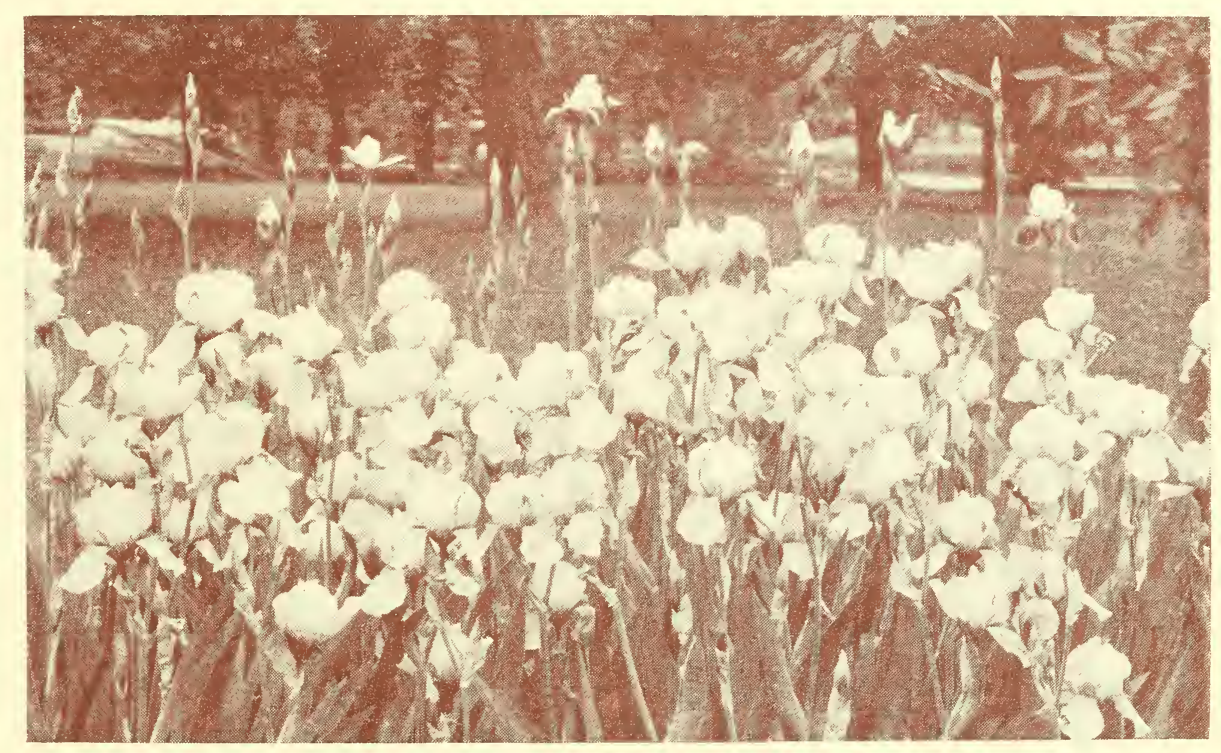

\section{Hardy Herbaceous Perennials}

A planting of Hardy Herbaceous Perennials affords a display of bloom from earliest spring until after frost comes in the fall, and gives the owner flowers that may be cut at any time for house and table decoration. They will mostly live all winter in the open ground and bloom freely every year. The following are the best varieties:

ALYSSUM Saxatile Compactum. Rock Madwort; Golden Tuft. Large, compact masses of yellow flowers in early spring; excellent for rockery. 1 foot. April, May.

ASTER Novae-angilae. Flowers large; purplish blue. 4 to 5 feet. Sept., Oct.

Tartaricus. One of the tallest and latestflowering Asters. Bluish vioiet. 5 to $6 \mathrm{ft}$. Oct. colored flowers. A splendid sort for natural planting. It blooms profusely in June.

Sweet Brier. The rosy pink flowers are followed in autumn by bright-colored seedpods; foliage very fragrant.

Wichuraiana (Memorial Rose). Beautiful small evergreen foliage. A grand trailer over all sorts of places. Fragrant, single. waxy white flowers are borne profusely in June.

Baby Rambler. One of the most practical, all-around roses ever put on the market. Rich crimson flowers in clusters as large as the popular Crimson Rambler, from which it is derived. Strictly a bush rose and can be grown in the house the same as any of the old-time pot-plant varieties. 
CHRYSANTHEMUMS. These are the prettiest and most popular of the early-flowering winter plants. They bloom freely in November and December and nothing makes a more cheerful display. The prevailing colors are white, yellow and red. Should be planted in pots and placed in the house where they will have the sun.

Maximum, Triumph. A strong-growing perennial about 2 feet in height, which continues in bloom from July until October; flowers daisy-like, 3 to 4 inches in diameter, with a golden center; of great substance, lasting a week or more when cut.

Shasta Daisy. Large, snowy white flowers, in bloom all summer and fall.

COREOPSIS lanceolata. Large golden yellow flowers; profuse bloomer throughout the summer.

CONVALLARIA majalis. Lily-of-the-Valley. Pure white flowers. 8 to 10 inches. May, June.

DIANTHUS (Plumarius semper florens). These are the old favorite hardy garden pinks, bearing sweet, clove-scented flowers in May and June.

Barbatus. Sweet William. In separate colors, red, white and rose. 2 feet.

DICENTRA (Dielytra) spectabilis (Bleeding Heart). A beautiful hardy border plant, with brilliant rosy heart-shaped flowers hanging in great profusion from a gracefully curved stem. May and June.

DELPHINIUM. Larkspur. Beautiful hardy plants, grown in borders for their stately habit and the handsome spikes of flowers, gorgeous in coloring. Excellent for cutting, and a mass planting is a feature of your garden to be proud of at blooming time-from June till late fall.

DIGITALIS. Foxglove. These old garden favorites are stately and elegant in summer when they produce bold masses of leaves and flower-spikes.

ERIANTHUS Ravennae. Resembles Pampas Grass, but blooms more abundantly. Valuable for the decoration of lawns.

EULALIA Japonica. A vigorous grower, with large plumes.

Gracillima univittata. A beautiful ornamental grass, with narrow graceful foliage.

Zebrina. One of the most beautiful of the ornamental grasses; yellow stripes run across the leaves.

FUNKIA, Coerulea. Blue flowers; broad leaves.

Subcordata grandiflora. Pure white, lilyshaped, large, fragrant flowers in clusters. This day lily is very attractive in bed or border.

GAILLARDIA grandiflora (Blanket Flower). The center of the flower is a dark reddish brown, while the orange petals are differently marked with bands of scarlet and crimson.

GYPSOPHILA (Baby's Breath). These beautiful flowers of easiest culture delight in open, rather dry places; they are especially desirable for rock-work; also good for covering unkempt places with a mass of delicate bloom.

HEMEROCALLIS flava (Yellow Day Lily). Large yellow flowers in clusters; very fragrant. May and June.

Fulva. Tawny Day Lily. Orange. 2 to 3 feet. July, Aug.

HIBISCUS Mallow Marvels. A robust type, with deeply cut foliage, and large flowers in shades of crimson, pink and white.

HOLLYHOCKS. No garden is complete without this grand, perfect and delicate flower. The flowers are as pure and perfect as those of the Camellia. Seeds sown in the spring will produce plants that bloom the second summer. Plants set out in the spring will flower about middle of summer, and for several years if not allowed to bloom too freely the first year.

IRIS, German (Iris Germanica). Popular herbaceous plants that come up year after year, and each season more floriferous than the previous. Desirable in shrubbery and borders, and are beautiful in groups by themselves. The flowers embrace a variety of colors and innumerable tints of blue, yellow and white.

Sibirica. Compact, tufted habit of growth, the stems bearing several clusters of the purplish blue flowers. 2 to 3 feet. May, June.

PEONIES. These old time favorites are being planted more than ever before. They all have showy, beautiful flowers, are perfectly hardy and flower early in the season before roses. They deserve a place in every garden. Are easily cultivated and require but little protection.

Augustin d'Hour. Dark brilliant solferinored, silvery reflex; medium to large bomb shape; showy bloom. Medium height; midseason.

Avalanche. Creamy white, gracefully flecked with carmine; large, compact, crown type; fragrant. Strong growth; midseason.

Alexandriana. Very large, light violet rose; early.

Asa Gray. Pale lilac, sprinkled with minute dots of deeper lilac. A very distinct variety.

Andre Lauries. Late, fragrant, red.

Boule de Neige. Milk-white, flecked with crimson; very large, globular and compact. Tall, erect growth; early midseason.

Couronne d'Or. Large, imbricated bloom, white reflexed yellow, central petals bordered carmine, golden stamens.

Delache. Violet-crimson; medium size; fairly compact, rose type. Strong, erect, vigorous growth; midseason to late.

Delicatissima. Delicate fine rose; very large, full and sweet.

Duc de Wellington. Very large, well formed sulphur white bloom, ideal habit, strong grower. 
Duchesse de Nemours. Very fine cup-shaped bloom, sulphur white with greenish reflex, fading to pure white.

Duchesse d'Orleans. Medium, large, compact, bomb. Guards deep pink, solferinored, center shaded salmon, with silvery reflex. Fragrant. Extra strong, tall, free bloomer. Mid-season.

Edulis superba. Dark pink, even color; large, loose, flat when fully open; fragrant. Strong, upright growth; early.

Felix Crousse. Very brilliant red. Medium to large, globular, typical bomb-shape; fragrant. Strong growth; midseason.

Festiva. Pure paper-white, with crimson markings in center; large, full; very fragrant. One of the best white varieties, Strong growth; midseason.

Festiva maxima. Paper-white with crimson markings in center. Very large and full, rose type. Very tall, strong growth; early.

Floral Treasure. Rose type, very large and showy. Pale lilac-rose color, an extra good commercial flower, of midseason blooming. A strong, tall upright grower.

Fragrans. One of the oldest, most sweetsmelling of the bright deep pinks, and in every way very satisfactory.

Golden Harvest. Bomb type, rather loose, medium sized flower of pale to peachblossom pink and creamy white center. Pleasant odor. Strong, vigorous dwarf grower. Free bloomer. Good commercial variety. Humei carnea. Light rose.

Jeanne d'Arc. Guards and center soft pink, collar cream-white shaded with sulphur. Midseason. Very similar to Golden Harvest.

Karl Rosenfield. Very large flower of globular semi-rose type. Vigorous, tall and free-flowering. As an early red it has no equal.

La Tulipe. Lilac-white. Fragrant. Strong grower; free bloomer. Late midseason. Good variety.

Louis Van Houtte. Beautiful shaped bloom, medium large flower, color fine violaceous red.

Mme. Calot. Pinkish white tinted with flesh color. Extra fine variety.

Mme. de Verneville. Very pretty flower, anemone shaped broad petals, those of the center very compact, color sulphur fleshy white, sometimes a carmine spot appearing.

Monsieur Krelage. Broad petals, bright currant red with amaranth center.

Marie Lemoine. Pure white, with creamwhite center; large, very compact, rose type; pleasing fragrance. Medium height; extra-strong stems; very late.

Meissonier. Medium size, bomb type; uniform brilliant purple-red; fragrant. Very tall, stems weak, free bloomer; midseason.

Mons. Jules Elie. Pale lilac-rose, silvery reflex; very large, compact globular; very fragrant. Tall, vigorous growth; early.

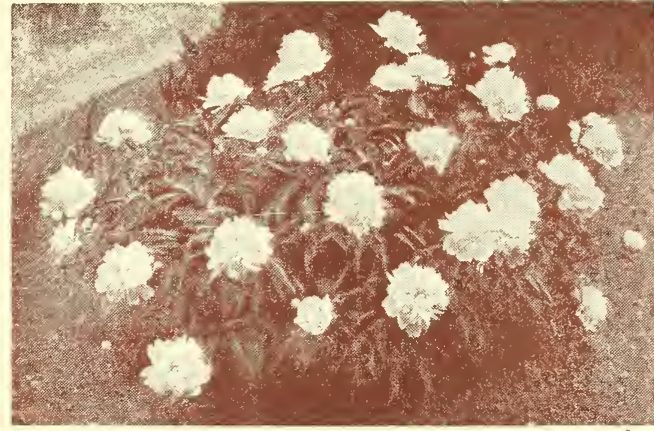

Festiva Maxima

Rose d'Armour. Delicate flesh-pink.

Rubra triumphans. Very dark crimson; large, loose, semi-double. Medium height; strong growth; early.

Officinalis rubra fl. pl. The old early crimson sort.

Queen Victoria (Whittleyi). Medium early, large, full compact bloom, center petals some years tipped with carmine spots, opens flesh white, cream center, changing to pure white. This is the one to plant for cut flowers.

Therese. Very large; medium compact; rose type; developing later a high crown. Light violet-rose, changing to a lilac-white in the center. Strong, erect, medium tall and very free bloomer. Midseason. One of the most desirable varieties.

PENTSTEMON barbatus Torreyi. Beard Tongue. Tall spikes of brilliant scarlet flowers. A most charming and effective border plant. 4 feet. June-Aug.

PHLOX. Familiar plants in old door-yards and valuable in all hardy borders. They are immense masses of bloom from the purest white to crimson. They grow 2 feet or more high and are perfectly hardy.

Alceste. Tall. Deep violet, shading to almost blue.

Bridesmaid. Medium. Pure white, clear carmine eye; blooms in large, round heads. Very attractive.

coquelicot. Medium. The finest and brightest red of all the phloxes. The color is a bright orange-scarlet.

Jeanne d'Arc. Tall. Large pyramidal heads of immaculate white; late.

I-a Vague. Tall. Pure mauve, with aniline red eye. One of the best varieties in our collection.

Madame P. Langier. Medium. Clear crimson, deeper eye. Considered one of the best.

R. P. Struthers. Tall. In our estimation, this is the bery best phlox grown todayit has no faults. It is a clear cherry-red, suffused with salmon shades, and deep red eye; fine large truss. The color is so clear and clean that each individual floret stands out as distinct as a cameo. 


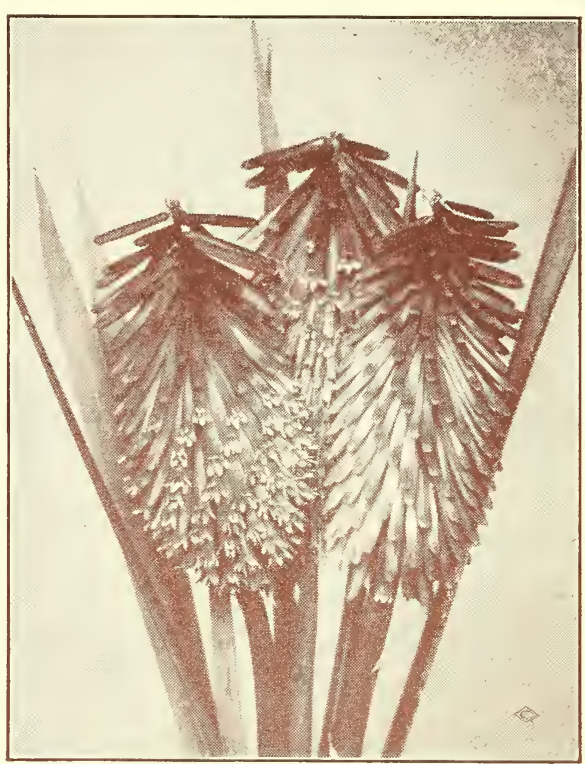

Tritoma Pfitzeri

Rijnstroom. Beautiful rosy-pink color not unlike that of Paul Neyron rose. A good strong grower and very free flowering.

Subulata Alba. A compact mass of elegant prostrate foliage, dainty white flowers in May and June.

Subulata Rosea. Same as above but with dainty pink flowers. This and Alba are fine for graves.

PHYSOSTEGIA (False Dragon-Head). Handsome perennials, forming dense bushes 3 to 4 feet high, bearing long spikes of delicate tubular flowers.

Virginia. Soft pink.

PLATYCODON grandiflora. Showy, bellshaped blue flowers in June and July.

Album semi-plenum.

RUDBECKIA (Golden Glow). A hardy perennial, growing 6 to 7 feet high and producing hundreds of bright golden flowers 2 to 3 inches in diameter, on long, graceful stems, forming immense heads of bloom. When once well established, will furnish an endless amount of flowers.

YUCCA filamentosa (Adam's Needle; Spanish Bayonet). An interesting tropicallooking plant, with stems 3 feet above the ground, covered with large, bell-shaped flowers on laterals, forming a perfect pyramid. Thread-like leaves.

\section{Summer and Autumn Bulbs}

\section{Require Taking Up in Fall to Keep From} Freezing.

CANNAS. Stately and highly ornamental plants, for both flowers and foliage. They attain a height of from 2 to 5 feet, and may be grown singly or in masses. Leaves green or brownish red; flowers scarlet, crimson, yellow, cream, etc., variously marked.

CAHLIAS, Double. Well-known autumnflowering plants, growing from 2 to 5 feet high, and producing a profusion of flowers of the most perfect and beautiful forms, varying in color from pure white to the darkest maroon. Very popular.

GLADIOLI. Of all our summer-flowering bulbs, the Gladioli stand eminently at the head as the most varied and beautiful class. The flowers are produced in spikes 2 feet high and upwards, the brilliant scarlet and crimson of some form a striking contrast with the delicate shades and pencilings of the light-colored varieties. By planting at intervals from May 1 to June 15 a succession of flowers can be had from July to October.

TIGRIDIAS (Shell Flower). One of our favorite summer-flowering bulbs and of the easiest culture, displaying their gorgeous tulip-like flowers of orange and scarlet from July to October.

TRITOMA Pfitzeri (Torch Lily). For color effect in orange-scarlet. nothing equals this free-flowering. easy-grown plant. The spikes are 3 to 4 feet high, and heads of bloom 10 to 12 inches long. July to September.

TUBEROSE, Double and Single. The flowers are very fragrant, on stems 3 to 4 feet high; blooms in autumn.

Pearl. More valuable than the common variety on account of its flowers being nearly double the size and imbricated like a rose, and in its dwarf habit, growing only $11 / 2$ to 2 feet.

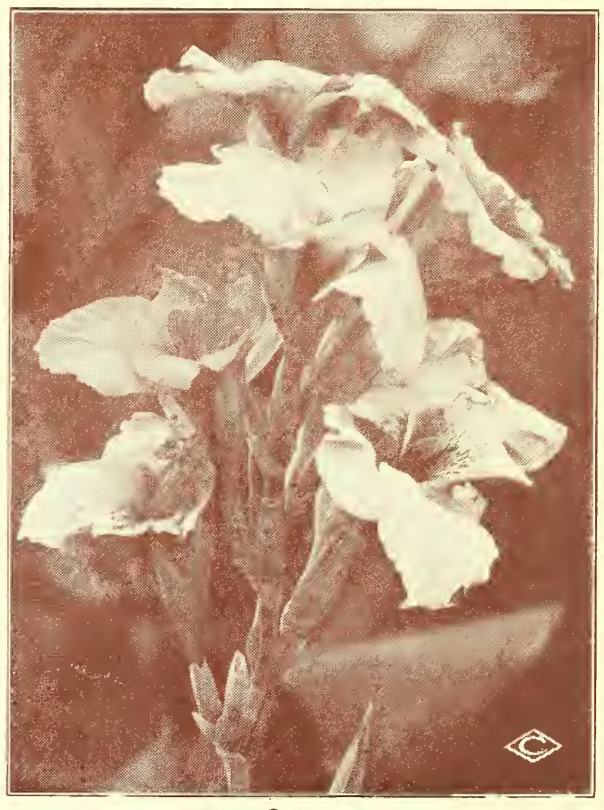

Canna 


\section{N D E X}

Pages

Almond, Flowering..........19

Althaea .................19

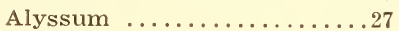

Ampelopsis ............23

Apples ................ 4-5

Apricots .............. 7

Aquilegia ...............27

Aralia .................19

Arbor-vitae ................17

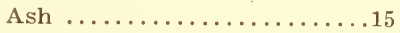

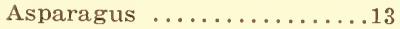

Aster ................27

Barberry ................. 19

Bignonia ...............23

Birch ...................15

Blackberries .............11

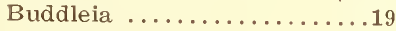

Butternut ...............15

Calycanthus .............19

Callicarpa ..............19

Campanula .............27

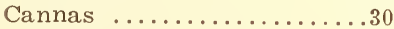

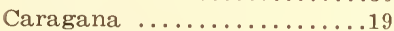

Caryopteris ..............19

Catalpa ................15

Celastrus ..............23

Cherries ............... 9

Chestnut .................15

Chrysanthemums .........27

Clematis ................23

Climbing Roses...........25

Coreopsis ...............28

Crab Apples.............. 5

Crab, Flowering...........15

Currant, Flowering........19

Currants ..............12

Dahlias .................. 30

Deciduous Trees..........15-17

Delphinium .............28

Desmodium .............20

Deutzia .................... 19

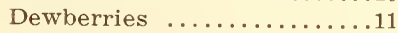

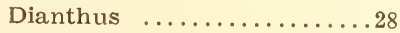

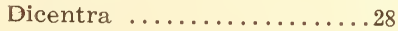

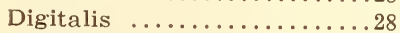

Dogwood, White............15

Dogwood
Pages

Elder .................20

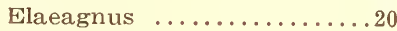

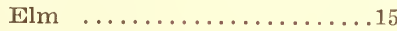

Erianthus $\ldots \ldots \ldots \ldots \ldots \ldots 28$

Eulalia ................28

Euonymus ............................

Evergreen Trees.........17-18

Exochorda ..............20

Fir ...................

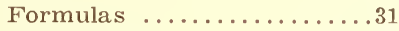

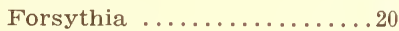

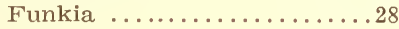

Gladioli ................. 30

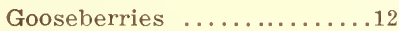

Grapes .............. 9-10

Gaillardia ...............28

Gypsophila ...........28

Hardy Climbing Vines.....23 Hemerocallis ............28 Herbaceous Perennials...27-30 Hibiscus ...............28 Hollyhocks ..............2s Honeysuckle, Bush .......20 Honeysuckle, Vines ........23 Hybrid Perpetual..........24-25

Hybrid Tea Roses.........26

Hydrangea ..............20

Iris $\ldots \ldots \ldots \ldots \ldots \ldots \ldots 28$

Judas Tree ..............15

Juniper .............18

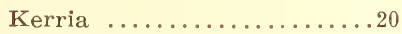

Koelreuteria ..............15

Lilac ................ 20-21

Lily-of-the-Valley ........28

Liquidambar ...............15

Locust $\ldots \ldots \ldots \ldots \ldots \ldots \ldots$

Magnolia .................16

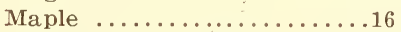

Miscellaneous Roses.......27

Moss Roses..............25

Oak .......................

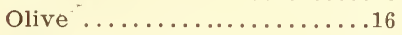

Ornamental Shrubs......19-22
Pages

Peaches..$\ldots \ldots \ldots \ldots \ldots .6 .6$ 6.

Fears .............. 5-6

Pentstemon .............29

Peonies ..............28-29

Philadelphus ............21

Phlox ..................29

Physostegia ...............30

Pine ...................18

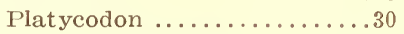

Plum, Flowering..........21

Plum, Purple-Leaved........16

Plums ................. 8

Polygonum .............23

Poplar .................16

Privet $\ldots \ldots \ldots \ldots \ldots \ldots \ldots 21$

Purple Fringe...........21

Quinces ................8

Raspberries .............11

Rhodotypos ..............21

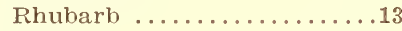

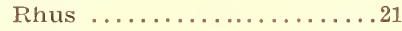

Roses ..............24-27

Rudbeckia ...............30

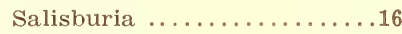

Snowberry .............21

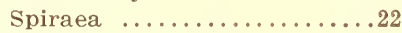

Spraying Calendar..........33

Spruce ................18

Strawberries ..........12-13

Summer and Autumn Bulbs.30

Sycamore ...............17

Syringa ................21

Tamarix ...............22

Tigridis . .............. 30

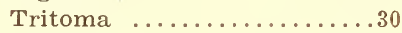

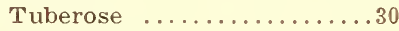

Tulip Tree..............17

Viburnum ..............22

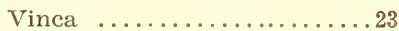

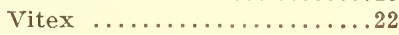

Walnut ...............17

Weeping Deciduous Trees...17

Weigela ...............22

Willow .................. 17

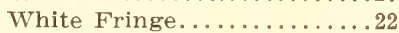

Wistaria ............... 23

Xanthoceras ............22

Yucca ..................... 


\section{Spray Formulas}

\section{Bordeaux Mixture}

Copper Sulphate (blue stone) $\ldots \ldots \ldots \ldots \ldots \ldots \ldots \ldots \ldots \ldots \ldots$ lbs.

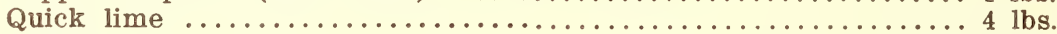

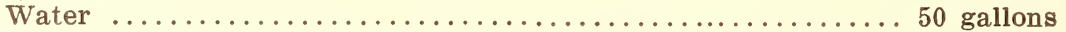

Dissolve the copper sulphate in water at the rate of one pound to one gallon, slake the quick lime and add sufficient water to it, so that when it is well stirred a gallon measure will hold one pound of the lime. These are "stock solutions" and are to be kept in separate vessels, preferably wooden barrels, as the copper sulphate will quickly corrode such metals as iron or galvanized iron.

When a batch of spray mixture is to be prepared, pour four gallons of the copper sulphate solution into a third vessel large enough to hold half the quantity needed to fill the spray tank; do likewise with the lime, adding twenty-one gallons of water to each. These dilute solutions are to be run at the same time into the spraying tank, letting the streams come together at the top of the tank. By diluting the stock solutions of lime and copper sulphate and running these dilute solutions together, a grade of bordeaux mixture is prepared which stays in suspension better and adheres to the foliage for a longer time than when the concentrated solutions are mixed.

\section{Lime-Sulphur}

Quick lime .................................... 50 lbs.

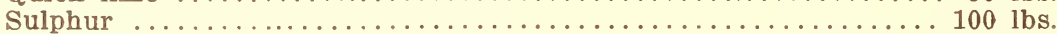

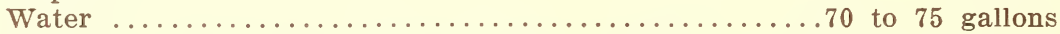

Sift the sulphur and add to enough hot water to make a thick paste; stir thoroughly. Slake the lime and as it is slaking add the sulphur; keep mixture stirred, adding sufficient water to keep in the form of a thin paste. As soon as slaking is finished, add enough water to bring to thirty gallons. Boil the whole quantity until mixture presents a dark red color, approximately three-quarters of an hour to an hour. This solution must be diluted for use. For dormant spray, use about one gallon to ten gallons of water. For summer spraying when trees are in leaf, use about one gallon to fifty gallons of water.

\section{Self-Boiled Lime-Sulphur}

Quick lime ................................... 8 lbs.

Sulphur ..................................... 8 lbs.

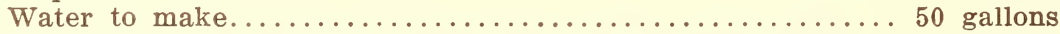

This material can be prepared in large lots, that is three or four times the quantity required by this formula, but in that proportion. Sift the sulphur and make into a paste with warm water. Start the lime slaking and as soon as this is well under way add moistened sulphur. Keep the mixture thoroughly stirred, adding sufficient water from time to time to keep it as a thin paste, but not wet enough to drown the lime. When the mass has stopped all noticeable signs of boiling, add enough water to make up to fifty gallons, and it is ready for use, but must be run through a fine strainer into the spray tank.

\section{Arsenate of Lead}

Acetate of lead (sugar of lead)........................... 11 ozs.

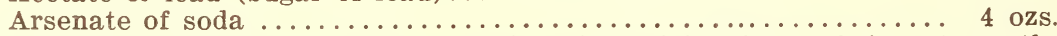

This material has come to be the standard insecticide for such insects as the codling moth and canker worm. Dissolve the acetate of lead in a gallon of water and the arsenate of soda in half a gallon of water in a separate vessel. When these are dissolved, pour them into fifty gallons of water and it is ready to apply. The liquid then has a milky appearance, due to the formation of arsenate of lead which settles in the course of time as a heavy white paste.

\section{Kerosene Emulsion}

One-half pound common bar soap, two gallons of water, two gallons of common kerosene. Dissolve the soap in hot water; while still hot, add the kerosene and stir or churn vigorously until a soft soap or cream-like substance is formed. When cold, dilute with water to make from ten to twenty-five gallons of liquid. This is used for the destruction of sucking insects, like aphides (plant lice), scale insects, etc. Always use soft water.

\section{Formula for Whitewash}

Slake $1 / 2$ bushel of fresh lime with hot water, keeping it covered during the process. Add $1 / 2$ peck of salt previously dissolved in warm water, 2 pounds of ground rice boiled to \&. thin paste. Stir in boiling hot $1 / 2$ pound Spanish Whiting, $1 / 2$ pint glue well dissolved in warm water. Dilute the above with 8 gallons of hot water, stirring it well to become thoroughly mixed. Strain through a fine sieve or strainer, and allow it to stand a few days before using. 


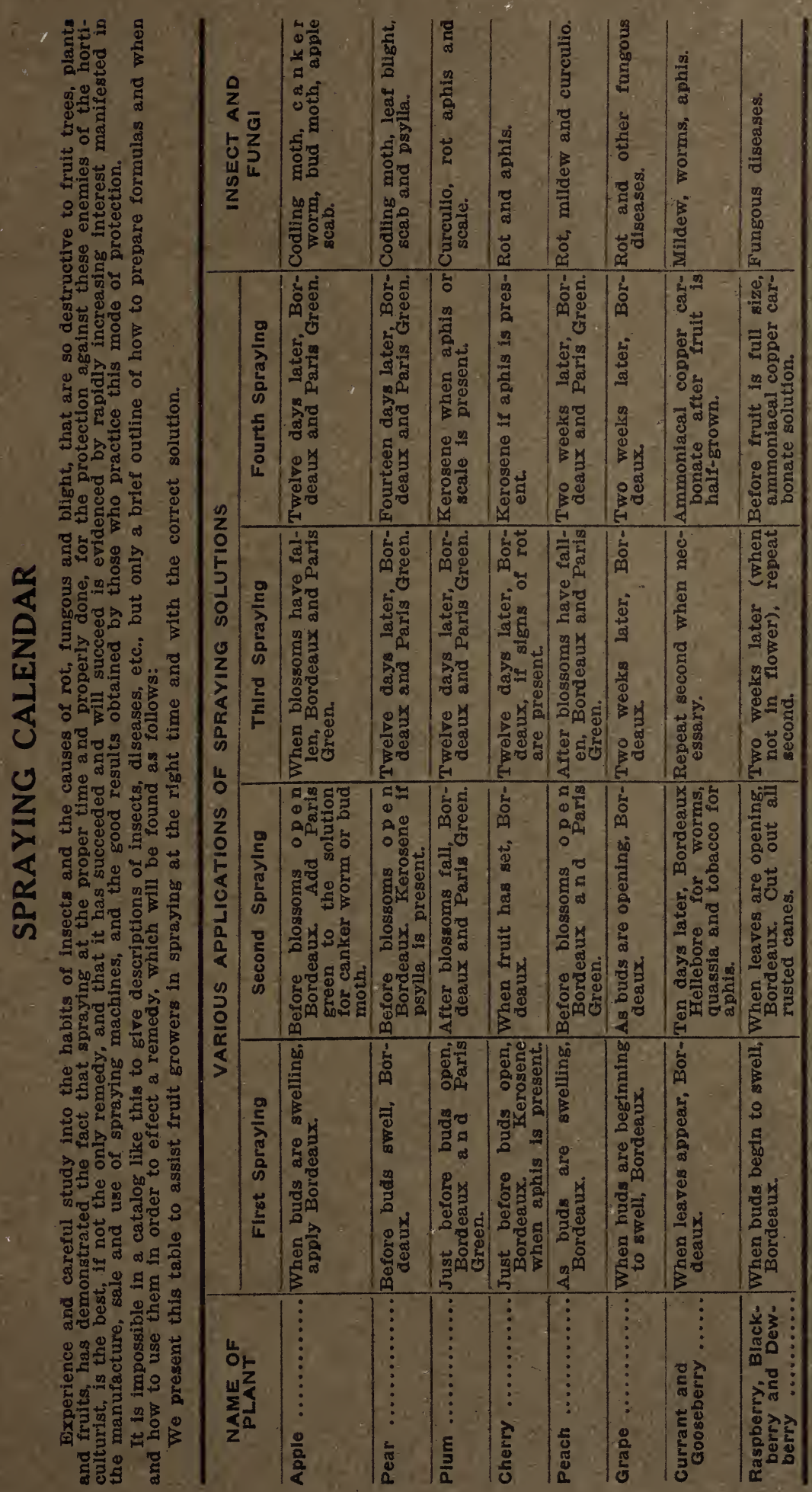


